\title{
7. MINERALOGY AND LITHOFACIES OF BLACK SEA SEDIMENTS LEG 42B DEEP SEA DRILLING PROJECT
}

\author{
Peter Stoffers and German Müller, Laboratorium für \\ Sedimentforschung, Universität Heidelberg, Heidelberg, Germany
}

\begin{abstract}
In general, three types of sediments were encountered in the three sites drilled during Leg 42B in the Black Sea: terrigenous, chemical (calcite, high-magnesian calcite, aragonite, dolomite, siderite), and biogenic (mainly diatomaceous). Terrigenous muds predominate in the Pleistocene whereas chemical sediments are abundant in the lower Pleistocene and Pliocene sediments. Biogenic constituents play a minor role only. Five different lithofacies could be recognized which are related to the changing environmental conditions in the Black Sea. The facies are: terrigenous muds, Seekreide, sapropelic diatomaceous clay, siltstone with dolostone intercalations, and siltstone. In many intervals a cyclic sedimentation of carbonate-free sapropelic sediments and carbonate layers were noted which is explained by an oscillating density boundary with anoxic conditions and the dissolution of carbonates below the interface. Stratification is often caused by the influx of marine waters into a fresh water Black Sea. The changes in the $\mathrm{Mg} / \mathrm{Ca}$ ratio of the Black Sea water determine the carbonate mineralogy. Dolomitized crusts, oolites, algae mats, intraclasts, and pellets found in the Pliocene sediments suggest deposition in a shallow marine to supratidal environment with subsequent diagenetic alteration under meteoric conditions. The Pleistocene sediments are basically influenced by the climatic fluctuations related to glacial and interglacial periods. A distinct shift in the importance of the different source areas is noted. The late Miocene-Pliocene to lower Pleistocene sediments characterized by abundant smectite are mainly derived from the south (Turkey) whereas the increased amount of illite and detrital dolomite which occur in the Pleistocene sediment sequence indicate sediment transport mainly from the north (Danube).
\end{abstract}

\section{INTRODUCTION}

The Black Sea is a semi-enclosed marine basin with an area of $432,000 \mathrm{~km}^{2}$ and a volume of $534,000 \mathrm{~km}^{3}$. It is situated between the Pontic Mountains to the south and the Caucasus and Crimean ranges to the east and north. The only connection to the Mediterranean Sea is the Bosporus Strait which has a sill depth of about 50 meters. It is this geographical location which makes the Black Sea one of the most unusual water bodies in the world. This sea has attracted the attention of scientists for a long time.

Numerous studies deal with the paleontology, mineralogy, or geochemistry of recent Black Sea sediments. Important early works are those of Andrusov (1890), Arkhangelsky (1928, 1930), Arkhangelsky and Strakhov (1938), and Strakhov (1954, 1961). In addition, over 40 reports on the sedimentary environment of the Black Sea have been published recently (Degens and Ross, 1974). These studies clearly indicate the importance of the shallow Bosporus connection for the environmental conditions within the Black Sea. The considerable climatic fluctuations and the corresponding sea level changes which occurred during the Pleistocene influenced the sedimentation within it. When the sea level dropped, the Black Sea became disconnected from the Mediterranean Sea and it changed from a marine to a lacustrine environment and back to a marine environment when sea level rose again. The DSDP drilling in the basin offered the opportunity to evaluate the climatic and geologic history of the Black Sea.

The purpose of this paper is to describe the mineralogy and lithofacies encountered in the three drill sites.

\section{LEG 42B DRILLINGS}

During Leg 42B three sites were drilled in the Black Sea (Figure 1). Details of the individual holes and their specific aspects can be found within the site chapters of this Initial Report. We briefly report here a summary of the major sedimentary findings.

\section{Site 379}

This site was drilled in the central part of the sea in water depth of 271 meters. It was continuously cored to 


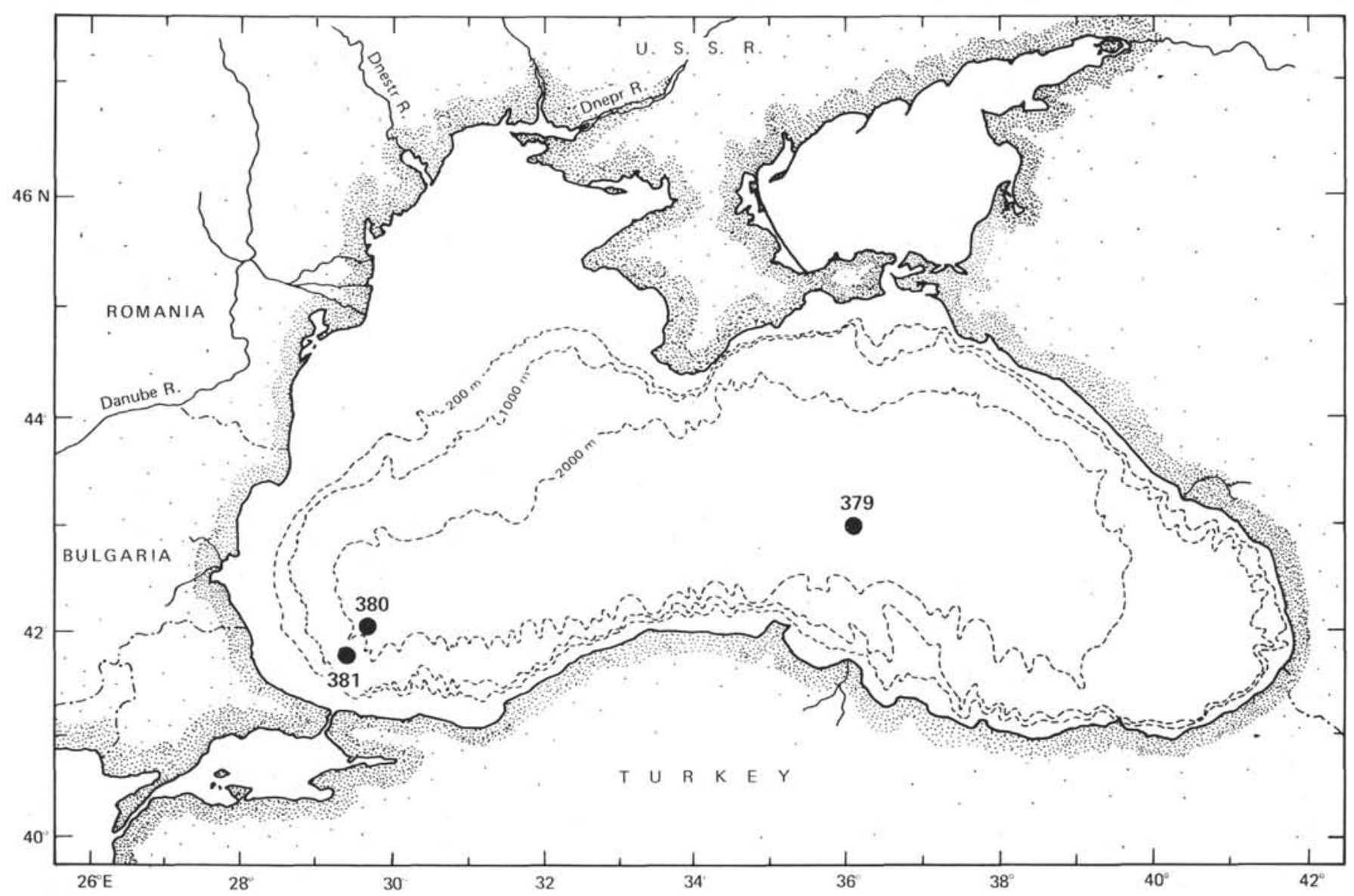

Figure 1. Leg $42 B$ drill sites.

a depth of 624.6 meters. In general, the whole sedimentary sequence can be considered as one large unit composed of dark greenish gray to dark gray terrigenous mud. Several small organic-rich sapropel layers are intercalated within the muds. Locally grayish-white carbonate-rich bands occur which indicate that, especially in the lower part of the hole, chemical sedimentation became more significant. The pollen data suggest a Pleistocene age (Traverse, this volume).

\section{Holes 380/380A}

This site was drilled in the western part of the Black Sea near the Bosporus in 2115 meters of water. The two holes at this site penetrated 1073.5 meters of sediment. Five distinct sedimentary units were identified; from top down they are:

Unit 1-Terrigenous sediments which include muds, sandy silts, and silty sands. Total thickness is 332.5 meters. The age is Pleistocene.

Unit 2-Various chemical sediments, aragonite, siderite, and calcite (lake chalk) interbedded in muds. Total thickness is 115.5 meters and the age is Pleistocene.

Unit 3-Lake Chalk (seekreide) including marls. Total thickness is 198 meters. The age is most probably Pleistocene.
Unit 4-Various chemical sediments of Pliocene age including calcitic, sideritic, aragonitic sediments which are interbedded in muds. The unit is characterized by the presence of abundant diatoms. Total thickness is about 220 meters.

Unit 5-Black siltstones containing dolomite and zeolite intercalations. Pollen data suggest a Pliocene or most probably Late Miocene age for this unit.' Total thickness is about 209 meters.

\section{Site 381}

This site was located nearer to the Bosporus, upslope from Holes $380 / 380 \mathrm{~A}$, in 1750 meters water depth. Drilling continued to a subsurface depth of 503.5 meters. The section at Site 381 can be divided, from top down, into four sedimentary units.

Unit 1-Terrigenous sediments including silts, silty clays, and clays. A sand interval is found at the base of this unit. Total thickness is 171 meters. The age is Pleistocene.

Unit 2-Various chemical sediments of probable Pliocene age (seekreide, aragonite, siderite) are interbedded in organic-rich muds which contain abundant diatoms. Total thickness is about 85 meters.

Unit 3-Pebbly mudstone, breccia, shellhash, sand. Recovery was less than $10 \%$. Total thickness is about 85 meters. 
Unit 4-Laminated siltstone with occasional intercalations of thin siderite and silty sand layers. Within the siltstone a brecciated interval is present. Total thickness is about 68 meters. Pollen data indicate a Miocene age for the lower most cores.

\section{METHODS AND ANALYTICAL PROCEDURE}

For textural studies the samples were dried, mixed, and desalted. Standard sieving and settling tube techniques were applied. Total carbonate was determined by use of an acidification-pressure bomb technique (Müller and Gastner, 1971).

X-ray analyses were performed on a Philips X-ray diffractometer under the following instrumental conditions: copper radiation, nickel filter, 36 kilovolts 20 milliamperes, $1^{\circ}$ per minute scanning speed, for special tests $0.2^{\circ} 2 \theta / \mathrm{min}$. Paper speed, scale, and time factor were chosen to produce optimum results. The amount of each mineral was estimated by the use of the X-ray computer program of the USGS at Woods Hole (Hathaway, unpublished). Data processing was described by Zemmel et al., in Volume 11, Initial Reports of the Deep Sea Drilling Project (1972).

Samples for clay mineral analyses were first treated with $10 \%$ hydrogen peroxide to remove organic matter, and with dilute acetic acid to expel carbonates. Clay smears were done on glass slides. Clay mineral analyses and the semiquantitative estimate of the amount of minerals present were done according to the methods described by Biscaye (1965).

The siderites and some of the dolomites were analyzed in a hydrofluoric perchloric acid decomposition. Individual elements were determined by atomic-absorption spectroscopy. Many of the samples were studied in thin sections under the petrographic microscope. Scanning electron microscope work on carbon and gold-coated samples was carried out on a Cambridge Stereoscan S 4. A total of about 400 samples have been analyzed. The results are presented in the appendix.

\section{SEDIMENT CONSTITUENTS OF LEG 42B SEDIMENTS}

As a result of shipboard and shore laboratory work, the various constituents identified in the Black Sea sediments are summarized in Table 1.

\section{Allochthonous Constituents}

\section{Volcanogenic Material}

Volcanogenic constituents are rare. They are restricted to the lower part of Hole $380 \mathrm{~A}$ and Site 381 . Two approximately $1-\mathrm{cm}$-thick tuff laminae were found in Core 37, Section 5 and in Core 41, Section 3 of Hole $380 \mathrm{~A}$. They contain abundant colorless glass shards, some idiomorphic quartz, and biotite. The refraction index indicates a dacitic composition. Besides these tuff laminae, glass shards are sporadically distributed throughout the Pliocene sediment sequence of Holes $380 \mathrm{~A} / 380$.

Cross-stratified laminae or graded beds of tuffaceous and zeolitic sandstone occur in Hole 380A, Cores 73 to 80 . The zeolite was identified as clinoptilolite.
TABLE 1

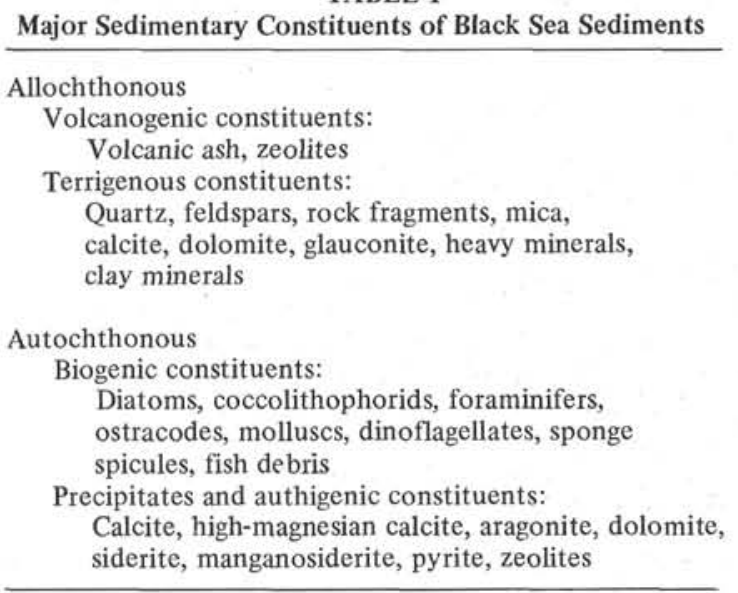

\section{Terrigenous Material}

Clay minerals, quartz, fedspars, and detrital carbonates (calcite and dolomite) are the most important terrigenous constituents of the Black Sea sediments. The distribution of these components in the individual sites is shown in Figures 2, 3, and 4. These figures represent the average mineralogical composition calculated from all anlyses over a 20 -meter interval.

\section{Clay Minerals}

Illite, smectite, kaolinite, and chlorite were determined by X-ray analyses of the $<2 \mu \mathrm{m}$ fraction. Many diffractograms of the air-dried sample have a low-angle shoulder of the 001 illite.

Moreover, a platform is often observed between the illite and chlorite peak which disappears after glycolation leaving behind a peak centered between $16.0 \AA$ and $17 \AA$. As shown by Matter (1974) and Hayes (1973), this mineral should be called a $17 \AA$ irregular mixed layer illite/montmorillonite. Because the amount of expandable layers could not be determined, this mineral is included in the smectite calculation. The dominant clay minerals are smectite and dioctahedral illite. Chlorite and kaolinite are only present in smaller quantities. X-ray characteristics of the chlorites indicate an iron-rich composition where the second and fourth order basal peaks are more intense than the first and third order peaks. The illite/smectite ratio in all three sites shows large fluctuations (Figure 5). In general, smectite is the most abundant clay mineral although there are certain intervals of the cores (Site $379,60-100 \mathrm{~m}$; Site $380,0-220 \mathrm{~m}$; Site $381,0-80 \mathrm{~m}$ ) which are more illitic.

A strong increase in the smectite content can be observed in the Pliocene to late Miocene sediments of Hole $380 \mathrm{~A}$ and Site 381 . This increase is accompanied by a general increase of the smectite crystallinity $(\mathrm{V} / \mathrm{p}$ ratio) (Figure 6) and is very pronounced in Site 381 from 0.6 to 0.9 .

\section{Quartz and Feldspar}

The quartz and feldspar content varies between 5\% and about $75 \%$ with an average in the order of $25 \%$. At 


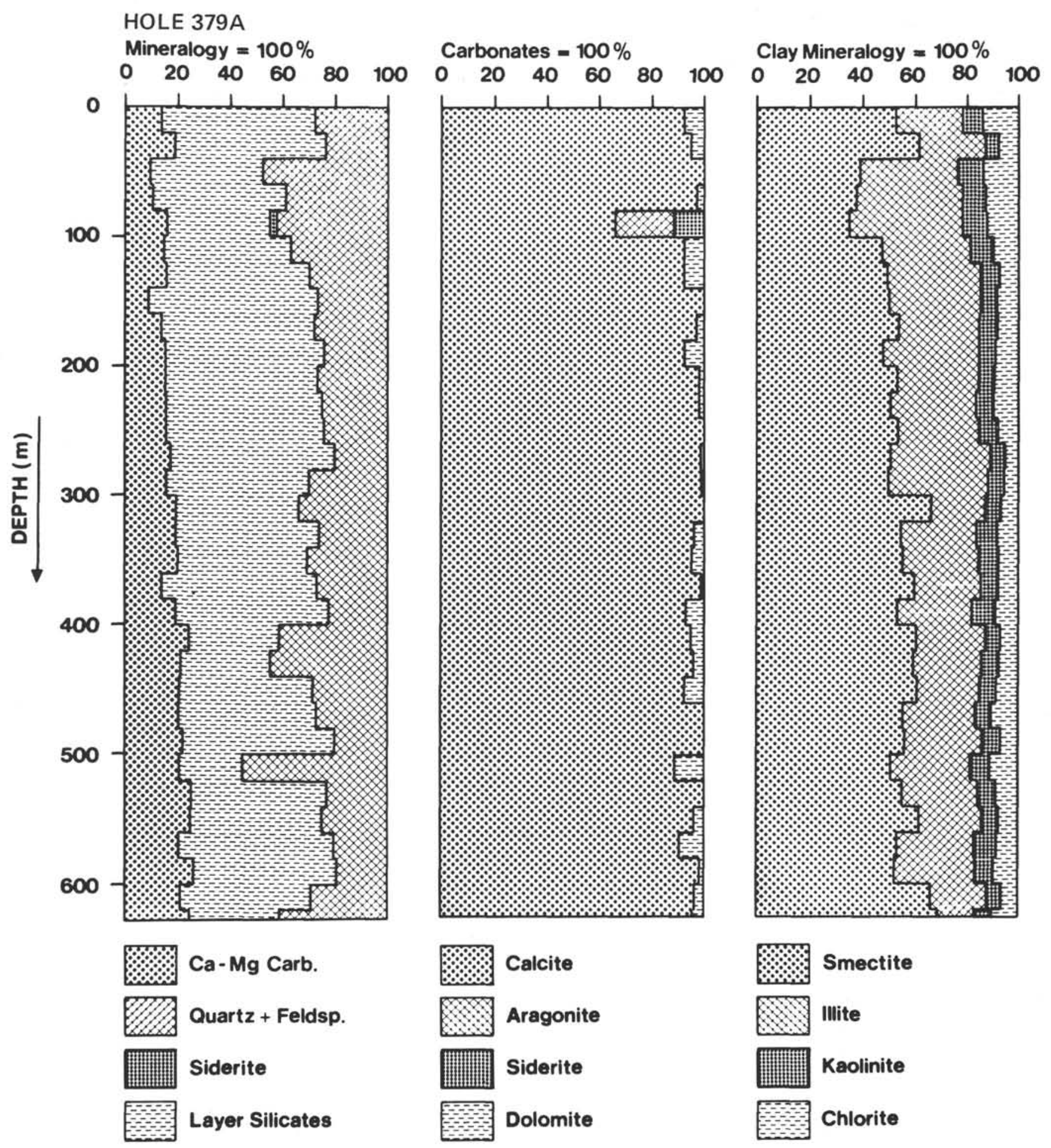

Figure 2. Bulk mineralogy, carbonates, and clay mineralogy of Hole $379 \mathrm{~A}$.

Holes 380/380A quartz and feldspar are more concentrated in the upper 350 meters whereas at Site 381 an increase towards the lower part of the hole can be observed (Figure 4). No obvious trend is found at Site 379 although some fluctuations in the quartz and feldspar content occur.

In general the quartz/feldspar ratio is $>1$, but there are certain intervals with higher feldspar contents. Plagioclase is the most abundant feldspar and ranges up to $33 \%$ (e.g., Hole 379A Core 10, Section 3). Potassium feldspar is present in quantities up to $8 \%$. In Holes $380 / 380 \mathrm{~A}$ and 381 feldspar is not as common as in Hole $379 \mathrm{~A}$ and hardly any potassium feldspar was detected.

\section{Rock Fragments}

In the coarse grained sand fraction, numerous rock fragments can be identified. In general, the rock 


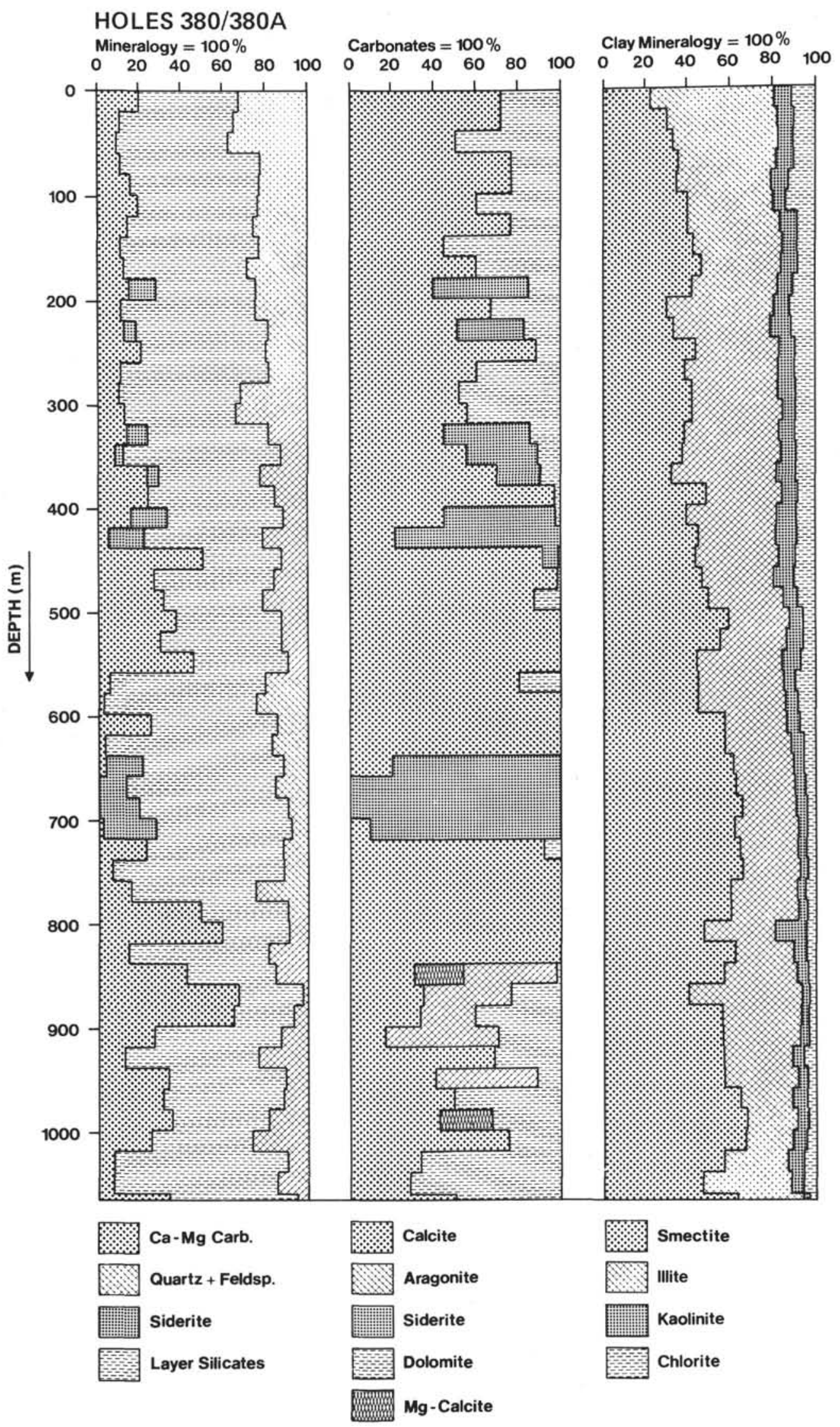

Figure 3. Bulk mineralogy, carbonates, and clay mineralogy of Holes 380/380A. 


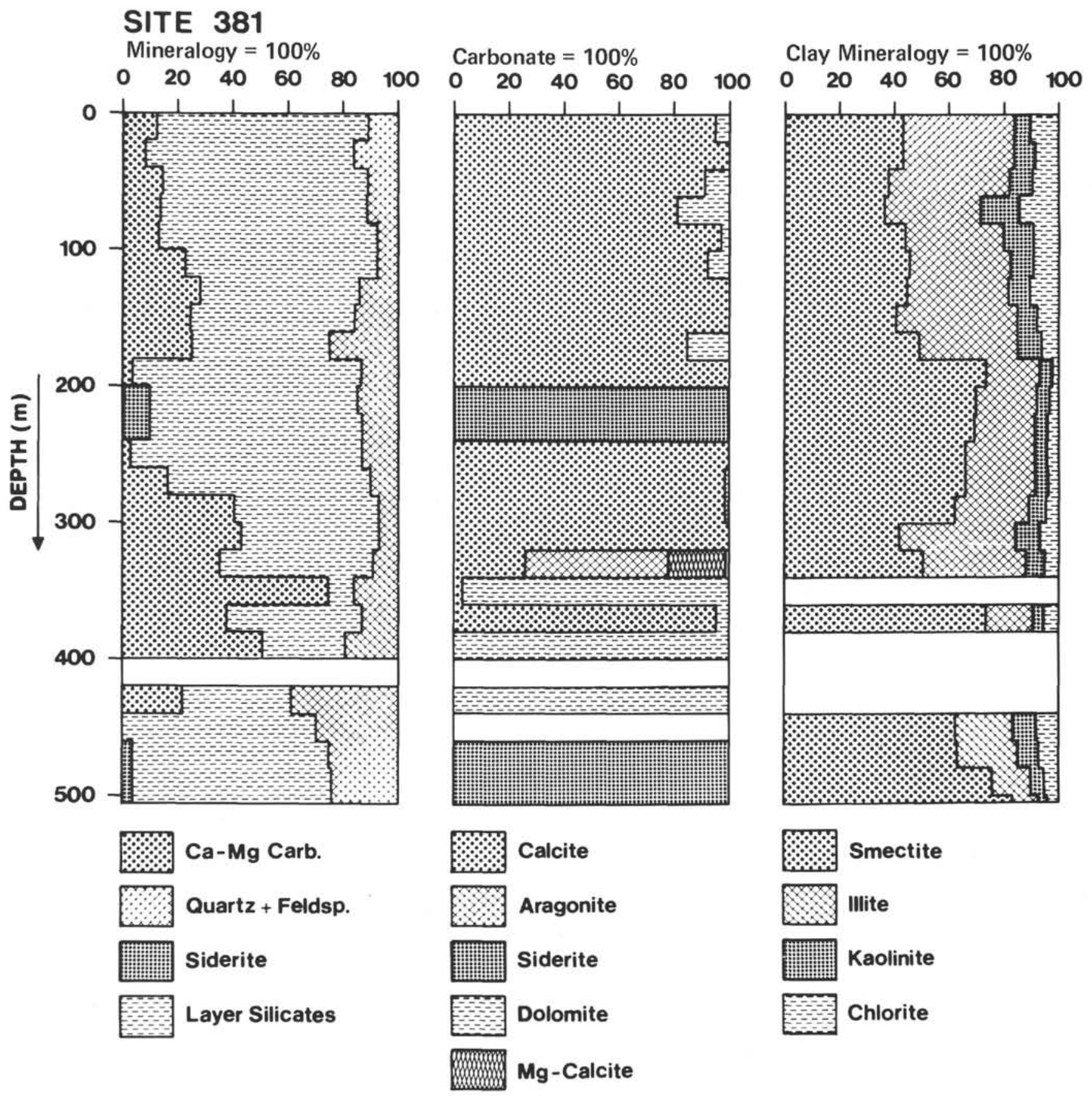

Figure 4. Bulk mineralogy, carbonates, and clay mineralogy of Site 381.

fragments are more abundant in Hole 379A than in the other two sites. They are basically of metamorphic and volcanic origin (e.g., slates, mica and chlorite schists, quartzites, serpentinites, andesites, and spilitic rocks). In Holes 380/380A and 381 carbonate rock fragments consisting of micritic to microsparitic limestones are also present.

\section{Heavy Minerals}

The most important non opaque heavy minerals in the sand fraction are garnet, amphiboles (green and brown hornblend, actinolite, alkali hornblende) epidotes (pistacite, zoisite, clinozoisite), and pyroxenes (augite, diopside, hypersthene). Traces of staurolite, kyanite, zircon, chloritoide, apatite, rutile, titanite, and tourmaline are present in some samples. A distinct heavy mineral pattern can be observed in the three sites in that pyroxenes are very abundant in Hole 379A whereas garnet is typical in the two western sites. A detailed heavy mineral study of the Black Sea samples can be found in a separate chapter (Trimonis et al., this volume).

\section{Light Minerals}

Besides quartz and feldspar, the sand fraction contains the light minerals muscovite, biotite, chlorite, and in some samples glauconite. Biotite and chlorite are more common in Hole 379A often in the form of 


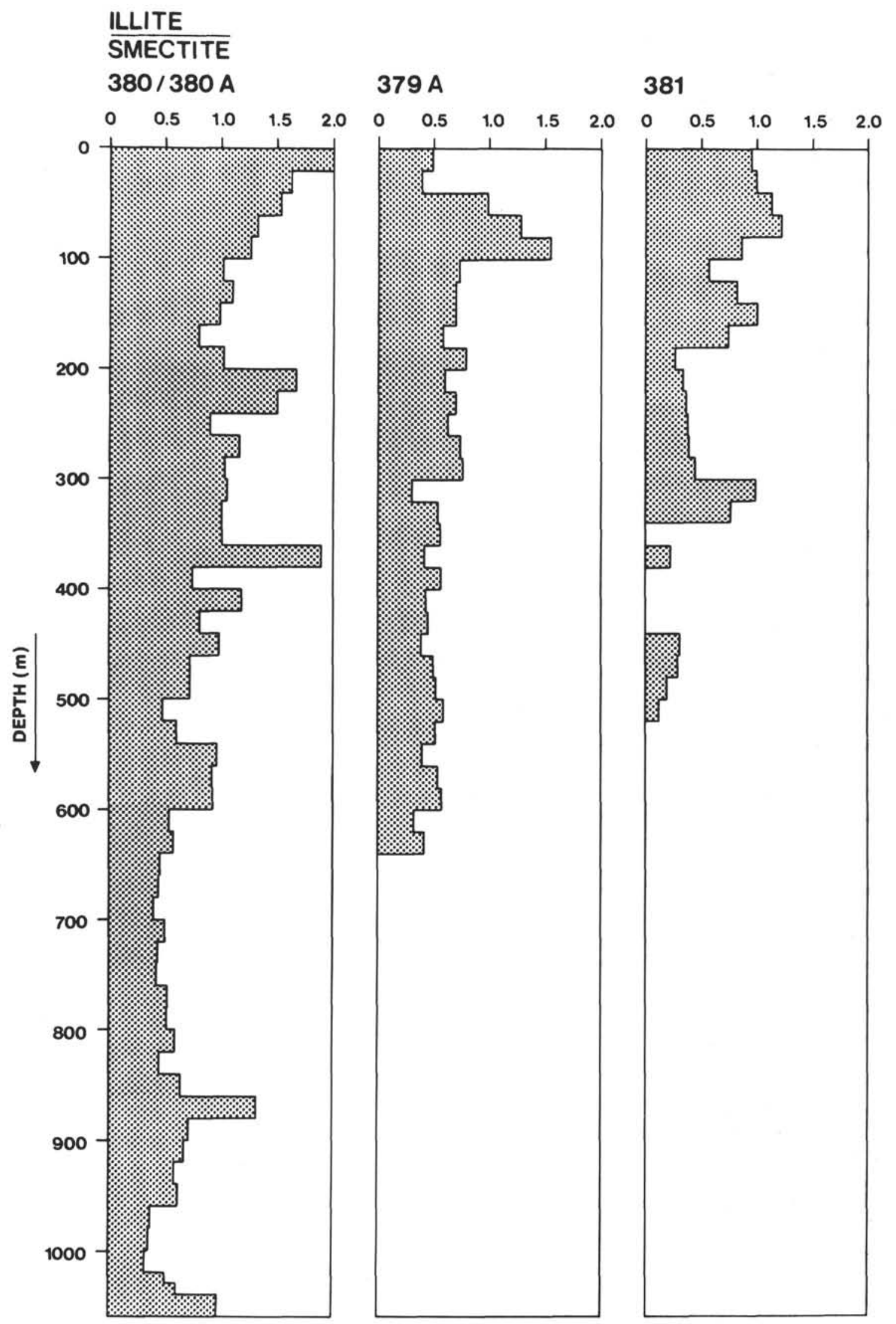

Figure 5. Illite/smectite ratio of Holes $379 \mathrm{~A}, 380 / 380 \mathrm{~A}$, and 381 . 


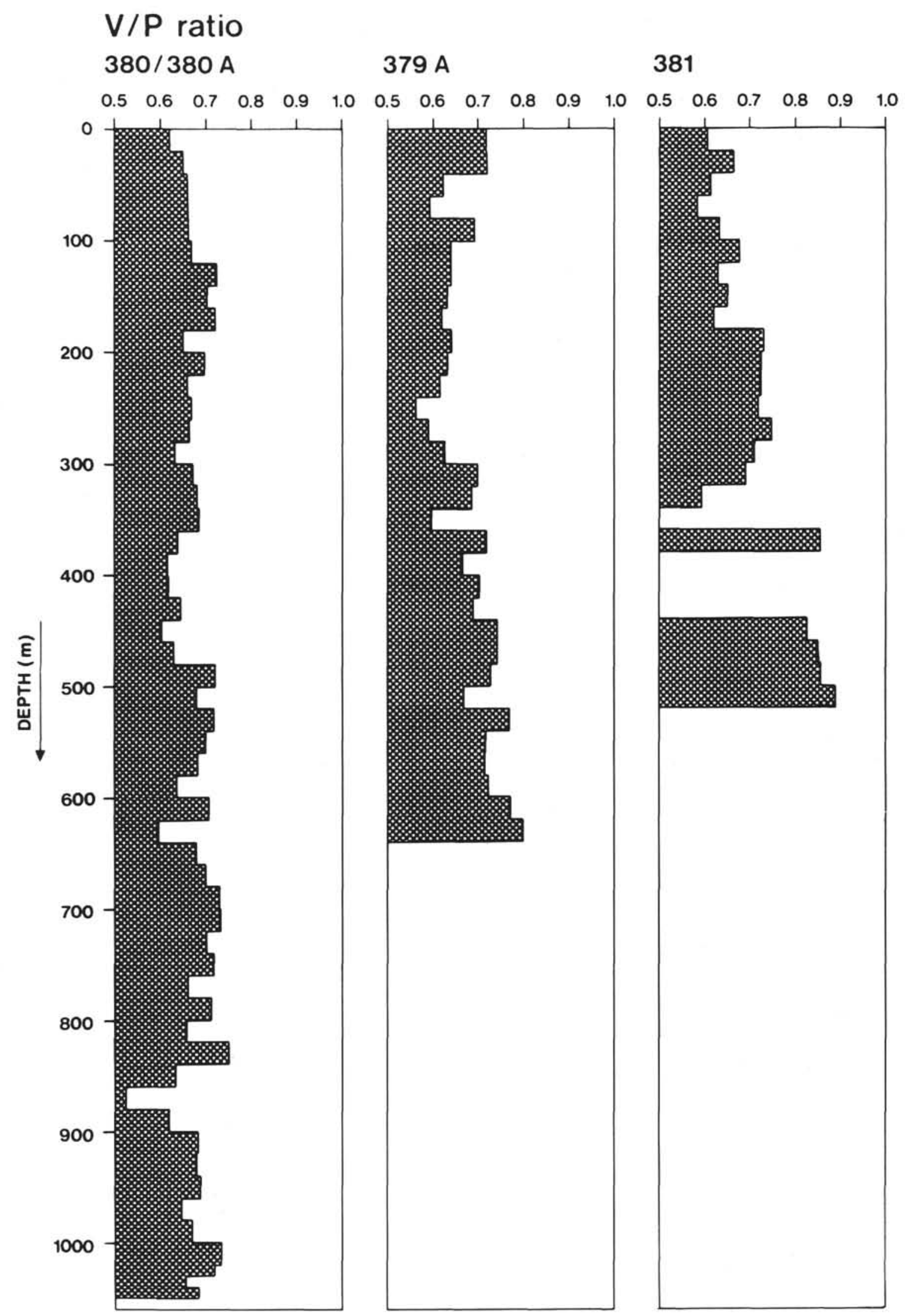

Figure 6. V/P ratio (crystallinity index after Biscaye (1965) of smectite in the three drill sites. 
bleached grains or grains revealing a sagenitic lattice. The highest glauconite content is found in Site 380 .

\section{Carbonates}

The total carbonate content of the three sites is given in Figure 7. Although there are great fluctuations, a general increase towards the lower half of the holes can be recognized. These higher amounts are related to the presence of authigenic carbonates whereas the low carbonate content (on the average about $10 \%$ to $15 \%$ ) found in the younger sediments, is thought to be of terrigenous origin. The detrital carbonate minerals are calcite and to a lesser extent dolomite.

The two western sites are distinguished from Hole $379 \mathrm{~A}$ by their higher dolomite content (up to $10 \%$ ). As can be seen from Figures 3 and 4, detrital dolomite sedimentation starts around 350 meters at Site 380 and about 180 meters at Site 381 . The dolomite which occurs in irregular grains is concentrated in the silt fraction.

Detrital calcite is noted in the clay as well as in the silt and sand fraction. A considerable amount of detrital nannofossils of Tertiary or Cretaceous age are present in some of the samples (Percival, this volume). In the coarse fraction carbonate rock fragments are common.

In Hole 379A, thin, light colored, sandy silt layers are present between 300 and 400 meters which contain abundant micritic carbonate concretions (Plate 1, Figures 4, 6).

\section{Autochthonous Constituents}

\section{Biogenic Components}

The Black Sea sediments cored on Leg 42B are distinguished from normal deep-sea sediments in that biogenic components are not as important as sediment builders. Indigenous fossils, like nannofossils and foraminifers, are generally rare and restricted to certain intervals.

Only diatoms occur in some abundance. Diatom-rich sediments are characterized by an olive hue. In most diatom-bearing intervals, the diatoms are of fresh water origin (Melosira, Stephanodiscus, Plate 2, Figure 6; Plate 5, Figures 5, 6). Besides the thicker fresh water diatom intervals, several smaller marine to brackishmarine diatom horizons could be identified (Schrader, this volume; Jouse' and Mukhina, this volume).

Indigenous calcareous nannofossils are restricted to thin layers which sporadically occur within the sediments (e.g., Site 379, Cores 11, 25, and 29; Site 380, Core 36; Hole 380A, Cores 55-57; Site 381, Cores 3638). Three assemblages of calcareous nannoplankton were found (Percival, this volume) and (Plate 2, Figures 3, 4). They are (1) Emiliania huxleyi, (2) Gephyrocapsa caribbeanica, and (3) Braarudosphaera bigelowi.

Benthonic foraminifers like Ammonia beccarii and Bolivina are described from certain sections (e.g., Site 379 , Core 11 or Site 381 , Core 37) (Gheorghian, this volume). Ostracodes, molluscs, dinoflagellates, siliceous spicules, and fish remains are scattered

\section{CARBONATE CONTENT}

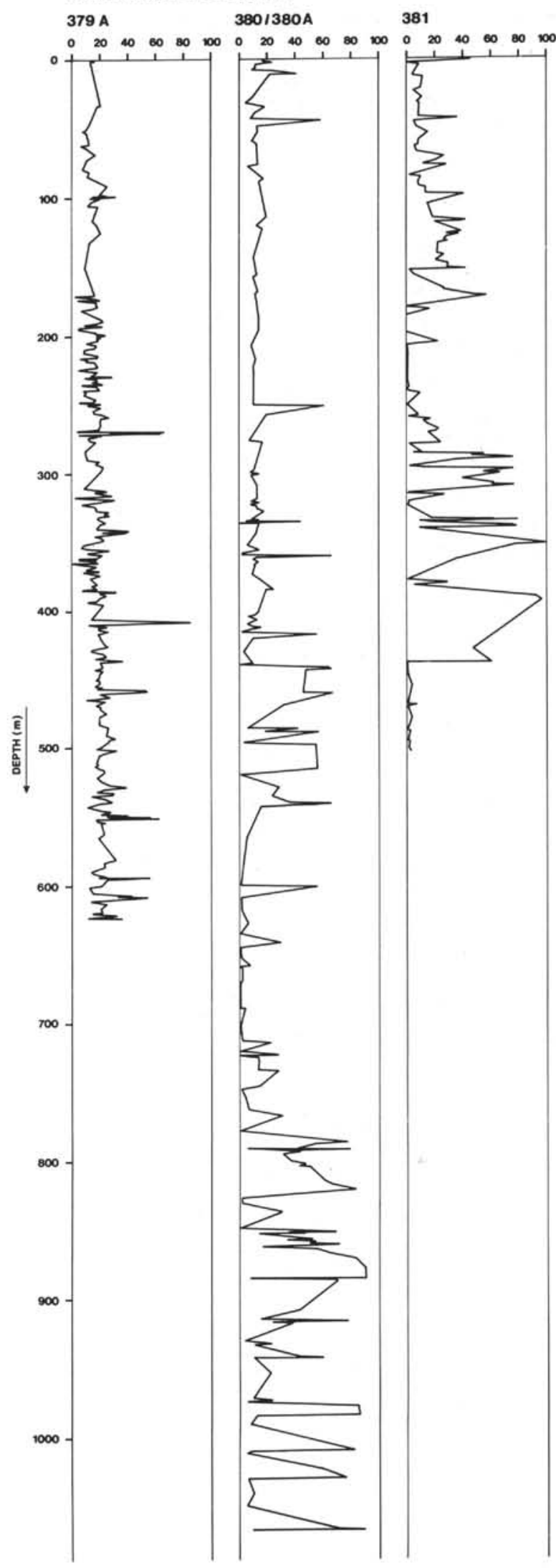

Figure 7. Total carbonate content of Holes $379 A, 380 /$ $380 \mathrm{~A}$, and 381 . 
throughout the sediments. In some cores (e.g., Hole 379A, Core 51) dinoflagellates are very abundant (Plate 2, Figure 5).

\section{Precipitates and Authigenic Constituents}

\section{Calcite}

The dominant nondetritic mineral in all sites is calcite which is concentrated in the silt fraction. The calcite occurs either in varve-like thin laminations or as white structureless massive beds (Plate 3, Figures 3, 5). The morphology of the calcite grains ranges from euhedral crystals to irregular grains (Plate 4). In most cases a strong indication of dissolution can be observed.

\section{High-magnesian Calcite}

High-magnesian calcite in amounts up to $15 \%$ was detected in only a few samples. It occurs as thin laminae in the predominately sapropelic sediments of Holocene and Pliocene age and is commonly associated with aragonite and biogenic calcite (coccolithophorides). The amounts of $\mathrm{MgCO}_{3}$ in the calcite structure range from 6 to 9 mole percent. In Core 57, Hole 380A, the presence of high-magnesian calcite seems to be related to biogenic constituents (Plate 5, Figures 2-4). This is supported by the higher $\mathrm{MgCO}_{3}$ content of about 11 mole percent.

\section{Aragonite}

Aragonite occurs as individual micro-layers within the sapropel sediments or in a varve-like finely laminated pattern (Plate 1, Figure 2). The highest aragonite content is about $80 \%$. In the sapropels, aragonite is always accompanied by the coccolithophore Braarudosphaera bigelowi. Scanning microscope pictures reveal a distinct difference between the two types of aragonite. In the sapropels, the aragonite exhibits a typical "rice or wheat grain" morphology with characteristic corrosion features (Plate 6). Often framboidal pyrite is present within these aragonite grains (Plate 6, Figure 2). In contrast, the laminated intervals are distinguished by idiomorphic columnar aragonite crystals, a part of which is seemingly composed of a sequence of individual tabular plates (Plate 6, Figure 6).

\section{Dolomite}

Authigenic dolomite (which is absent in Hole 379A) is found in the lower part of Hole $380 \mathrm{~A}$ and Site 381 only. It occurs as lithified layers, dolomitized crusts and oolites (Plate 1, Figure 5; Plate 7, Figures 3, 4). Many dolomites show a displacement of the diffraction maxima indicating about $5 \%$ to $7 \%$ excess calcium in the dolomite structure. The X-ray analyses of the dolomites found in the sideritic intervals as well as their higher refraction indices suggest the presence of a ferroan dolomite (ankerite).

\section{Siderite and Manganosiderite}

Siderite is present in distinct sections in all three sites. At Hole 379A it occurs within the sapropelic sediments encounted in Core 11. In the other two sites it is found in the diatomaceous sapropelic intervals either in light olive gray bands, as spindle-like crystals (Plate 7, Figures 5, 6; Plate 8, Figures 1-6) within the soft sediment, or as hard lithified layers and concretions. Xray and chemical analyses (Table 2 ) indicate a considerable amount of manganese in the siderite lattice. The $\mathrm{Fe} / \mathrm{Mn}$ atomic ratio varies between 4.4 and 55.6. The results show a distinct difference between the two siderite intervals encountered: In the upper unlithified siderite interval the ratios are high (average ratio 36.4) whereas in the lower lithified section the ratios are generally lower (average ratio 13.1). No enrichment in trace metals could be detected.

\section{Pyrite}

Pyrite is present throughout the cores in the form of irregular grains, as casts and replacement of burrows, and in thin distinct layers often composed of framboids.

\section{Zeolites}

Zeolites were noted only in the lower part of Hole $380 \mathrm{~A}$ (Cores 73 to 80 ). They are restricted to thin light colored silty sand layers within the black siltstones (Plate 1, Figure 1). X-ray diffraction analyses exhibit the presence of clinoptilolite (Plate 7, Figures 1,2)

\section{SEDIMENT COLOR}

In general the sediment colors reflect the state of oxidation. Red and brownish colors indicate the presence of iron oxides whereas reduction results in dark greenish to black colors.

The Black Sea sediments cored on Leg 42B are characterized by the predominance of dark greenish to dark gray colors. This color monotony is interrupted by light to medium gray carbonate-rich intervals. A more olive hue is typical for diatom rich zones. Brown to slightly red colors are rare and restricted to the Pleistocene sediments encountered at the three sites. They occur at Hole 379A, Core 29, Site 380, Core 40, Hole 380A, Cores 4, 5, 8, and Site 381, Cores 6 and 7. Medium bluish to bluish gray colors are common only in the first couple of cores at Site 381. Black colors prevail in the carbonaceous deposits and are typical for the distinct sapropels present in the three sites (e.g., Hole 379A, Cores 11, 25, and 29).

\section{SEDIMENT STRUCTURES}

Banding, bedding, laminations, grading, slumping, brecciation, and bioturbation are the sedimentary structures observed in the Black Sea drill cores. Banding characterized by small-scale distinct color alteration without changes in the sediment composition is found in some terrigenous intervals (e.g., Hole 379, Core 19). The color changes are most probably due to differences in the clay content and the oxidation state of the iron.

Bedding involves different lithologies. It is the most frequent sedimentary structure in the Black Sea cores. A typical example is Core 29 of Hole 379 A where bedding is present as alteration of dark greenish gray terrigenous mud, black sapropels, and structureless 
TABLE 2

Chemical Analyses Siderite - Samples Leg 42B

\begin{tabular}{|c|c|c|c|c|c|c|c|c|c|c|c|c|c|c|}
\hline $\begin{array}{c}\text { Sample } \\
\text { (Interval in } \mathrm{cm} \text { ) }\end{array}$ & $\begin{array}{l}\mathrm{Fe} \\
(\%)\end{array}$ & $\begin{array}{l}\mathrm{Mn} \\
(\%)\end{array}$ & $\begin{array}{c}\mathrm{Cu} \\
\text { (ppm) }\end{array}$ & $\underset{(\mathrm{ppm})}{\mathrm{Zn}}$ & $\begin{array}{c}\mathrm{Ni} \\
(\mathrm{ppm})\end{array}$ & $\begin{array}{c}\text { Co } \\
\text { (ppm) }\end{array}$ & $\begin{array}{c}\mathrm{Cr} \\
\text { (ppm) }\end{array}$ & $\begin{array}{c}\mathrm{Pb} \\
(\mathrm{ppm})\end{array}$ & $\underset{(\mathrm{ppm})}{\mathrm{Cd}}$ & $\begin{array}{c}\mathrm{V} \\
(\mathrm{ppm})\end{array}$ & $\begin{array}{l}\mathrm{Ca} \\
(\%)\end{array}$ & $\begin{array}{l}\mathrm{Mg} \\
(\%)\end{array}$ & $\begin{array}{c}\mathrm{Sr} \\
\text { (ppm) }\end{array}$ & $\begin{array}{l}\mathrm{Fe} / \mathrm{Mn} \\
\text { Atomic } \\
\text { ratio }\end{array}$ \\
\hline \multicolumn{15}{|l|}{ Hole 380} \\
\hline $\begin{array}{l}21-4,45-46 \\
37-1,60-63 \\
37-2,41-43 \\
38-2,24-26 \\
40-1,80-82\end{array}$ & $\begin{array}{l}12.0 \\
22.0 \\
16.3 \\
13.96 \\
15.5\end{array}$ & $\begin{array}{l}0.30 \\
0.54 \\
0.29 \\
0.25 \\
0.28\end{array}$ & $\begin{array}{l}42 \\
20 \\
23 \\
26 \\
23\end{array}$ & $\begin{array}{l}79 \\
59 \\
64 \\
81 \\
83\end{array}$ & $\begin{array}{l}50 \\
52 \\
82 \\
68 \\
52\end{array}$ & $\begin{array}{r}10 \\
7 \\
8 \\
11 \\
10\end{array}$ & $\begin{array}{r}128 \\
53 \\
68 \\
68 \\
63\end{array}$ & $\begin{array}{r}5 \\
3 \\
12 \\
12 \\
11\end{array}$ & $\begin{array}{l}0.18 \\
0.27 \\
0.23 \\
0.24 \\
0.14\end{array}$ & $\begin{array}{l}54 \\
52 \\
56 \\
71 \\
63\end{array}$ & $\begin{array}{l}6.7 \\
6.6 \\
7.4 \\
5.6 \\
5.9\end{array}$ & $\begin{array}{l}1.9 \\
1.43 \\
1.55 \\
1.72 \\
1.67\end{array}$ & $\begin{array}{l}515 \\
200 \\
258 \\
230 \\
200\end{array}$ & $\begin{array}{l}38.18 \\
39.80 \\
54.72 \\
55.56 \\
54.90\end{array}$ \\
\hline \multicolumn{15}{|l|}{ Hole $380 \mathrm{~A}$} \\
\hline $\begin{array}{l}1-3,111-113 \\
4-4,122-123 \\
8-2,117-119 \\
8-5,148-150 \\
9-1,126-128 \\
10-1,148-150 \\
12-1,68-70 \\
12-4,93-95 \\
34, \mathrm{CC} \\
36-2,80-82 \\
36-6,134-136 \\
39-3,102-104 \\
39-3,109-110 \\
40-5,60-63 \\
42-1,5-7 \\
42-4,40-42\end{array}$ & $\begin{array}{l}13.3 \\
22.0 \\
13.38 \\
25 \\
18.22 \\
12.38 \\
25.0 \\
13.0 \\
30.0 \\
28.2 \\
31.6 \\
23.6 \\
23.25 \\
31.6 \\
30.0 \\
19.24\end{array}$ & $\begin{array}{l}0.36 \\
0.43 \\
0.51 \\
0.71 \\
0.76 \\
0.58 \\
1.93 \\
0.63 \\
1.93 \\
2.90 \\
1.70 \\
1.48 \\
1.44 \\
7.00 \\
2.59 \\
0.98\end{array}$ & $\begin{array}{l}42 \\
23 \\
29 \\
20 \\
35 \\
42 \\
29 \\
35 \\
17 \\
13 \\
13 \\
29 \\
22 \\
12 \\
15 \\
20\end{array}$ & $\begin{array}{l}76 \\
61 \\
76 \\
59 \\
77 \\
93 \\
48 \\
74 \\
40 \\
38 \\
41 \\
90 \\
63 \\
28 \\
38 \\
54\end{array}$ & $\begin{array}{l}52 \\
56 \\
48 \\
43 \\
56 \\
60 \\
77 \\
55 \\
48 \\
91 \\
35 \\
77 \\
62 \\
23 \\
25 \\
52\end{array}$ & $\begin{array}{r}5 \\
6 \\
8 \\
6 \\
7 \\
10 \\
9 \\
10 \\
5 \\
7 \\
3 \\
4 \\
5 \\
3 \\
7 \\
6\end{array}$ & $\begin{array}{r}139 \\
53 \\
118 \\
49 \\
74 \\
139 \\
43 \\
118 \\
30 \\
43 \\
41 \\
49 \\
99 \\
26 \\
64 \\
51\end{array}$ & $\begin{array}{r}5 \\
9 \\
7 \\
8 \\
8 \\
14 \\
10 \\
21 \\
\\
8 \\
8 \\
8 \\
8 \\
6 \\
5 \\
10 \\
5\end{array}$ & $\begin{array}{l}0.15 \\
0.15 \\
0.20 \\
0.10 \\
0.26 \\
0.22 \\
0.10 \\
0.15 \\
0.07 \\
0.13 \\
0.10 \\
0.64 \\
0.22 \\
0.05 \\
\\
0.33\end{array}$ & $\begin{array}{l}62 \\
50 \\
56 \\
49 \\
95 \\
72 \\
44 \\
40 \\
39 \\
36 \\
39 \\
44 \\
48 \\
38 \\
44 \\
60\end{array}$ & $\begin{array}{l}7.0 \\
5.7 \\
6.0 \\
4.6 \\
3.8 \\
5.6 \\
4.9 \\
9.0 \\
4.6 \\
4.2 \\
2.3 \\
3.1 \\
2.4 \\
1.8 \\
2.2 \\
5.6\end{array}$ & $\begin{array}{l}1.74 \\
1.34 \\
1.5 \\
0.97 \\
1.36 \\
1.62 \\
1.13 \\
1.47 \\
0.62 \\
0.52 \\
0.67 \\
0.94 \\
0.94 \\
0.26 \\
0.84 \\
1.1\end{array}$ & $\begin{array}{r}450 \\
188 \\
450 \\
188 \\
296 \\
385 \\
258 \\
450 \\
248 \\
230 \\
50 \\
372 \\
450 \\
60 \\
515 \\
340\end{array}$ & $\begin{array}{r}36.92 \\
50.00 \\
25.81 \\
34.88 \\
23.91 \\
20.95 \\
12.82 \\
20.00 \\
15.38 \\
9.47 \\
18.12 \\
15.61 \\
16.03 \\
4.40 \\
11.46 \\
19.10\end{array}$ \\
\hline \multicolumn{15}{|l|}{ Site 381} \\
\hline $23-4,90-92$ & 13.22 & 1.16 & 50 & 90 & 77 & 9 & 100 & 12 & 0.24 & 96 & 1 & 0.89 & 188 & 11.37 \\
\hline
\end{tabular}

medium bluish gray calcareous sediments (Plate 3, Figure 3).

Interlayering of calcitic or siderite, terrigenous and diatomaceous sediments is characteristic for the lower half of Hole 380A and Site 381. In the Pliocene section of Hole $380 \mathrm{~A}$, lithified dolomite layers as well as zeolite laminae are interbedded in the black siltstones (Plate 1, Figure 1).

A great variety of finely laminated sediments which comprises sapropels, calcareous sediments, clays, and siltstones occur in the Black Sea cores. A unique sediment type, a varved clay similar to glacial varves, is found in Hole 380A Cores 4, 5, and 8. Individual laminae are 1 to $2 \mathrm{~mm}$ thick. The couplets consist of alternating pale brown and pale olive-gray laminae (Plate 3, Figure 4). Finely laminated carbonates, which are either calcitic or aragonitic, are present in Hole 380A, Cores 23-34, 47-57 and in Site 381, Cores 32-35.

Individual laminae range from 0.1 to $2 \mathrm{~mm}$ (Plate 3, Figure 5). The Pliocene to upper Miocene black siltstones of Hole $380 \mathrm{~A}$ and Site 381 also show abundant evidence of laminations. Graded beds were noted in many intervals of the terrigenous muds. The silt and sand layers are up to several centimeters thick. Most of the coarser grained beds have sharp upper and lower contacts (Plate 1, Figure 8; Plate 3, Figure 6), although upper gradational transitions also occur. In many beds the grading is rather indistinct.

Large-scale slumping appears in the calcite sediments of Hole $380 \mathrm{~A}$, Cores 13 to 34 . Disruption of laminae and folding indicate major disturbances. Some of these structures, however, may also be due to the drilling operation. Brecciated sediments are encountered at
Hole $380 \mathrm{~A}$, Core 58 and Site 381 , Cores 39 to 47 and 51. In Core 58 pebble-sized, angular to subrounded clasts are found in a dark gray mudstone matrix (Plate 1, Figure 5). The breccia present in Core 51 of Site 381 shows evidence of soft sediment deformation.

Bioturbation in form of mottling and burrows are described from several intervals. Well-developed burrow structures occur in distinct horizons, 1 to $3 \mathrm{~cm}$ thick, in Cores 50, 58, 60, 65 of Hole 379A (Plate 3, Figure 2). The burrows are irregular and run more or less obliquely or parallel to the bedding plane.

\section{LITHOFACIES}

Based on mineralogy, color, and sedimentary structure, a great variety of facies types can be identified in the Black Sea sediments. In order to simplify this, only the major facies are considered. They are: (1) terrigenous mud/mudstone; (2) seekreide (lake-chalk); (3) sapropelic diatomaceous clay; (4) black siltstone with intercalated dolostone; (5) siltstone. The occurrence of these five major facies within the three drill sites is shown in Figure 8.

\section{Terrigenous Mud (mudstone) (Plate 9, Figures 3-6)}

The dominant lithology of this facies is a dark greenish gray mud with frequent intercalations of sandy silts and sand. The muds are generally structureless. Bedding is indicated by intercalated coarse-grained material which often are graded. The facies comprises the entire sequence drilled at Hole 379A, the upper 300 meters of Site 380 , and the first 170 meters of Site 381 . The facies is characterized by the dominance of layer silicates and the high amount of quartz and feldspar. 


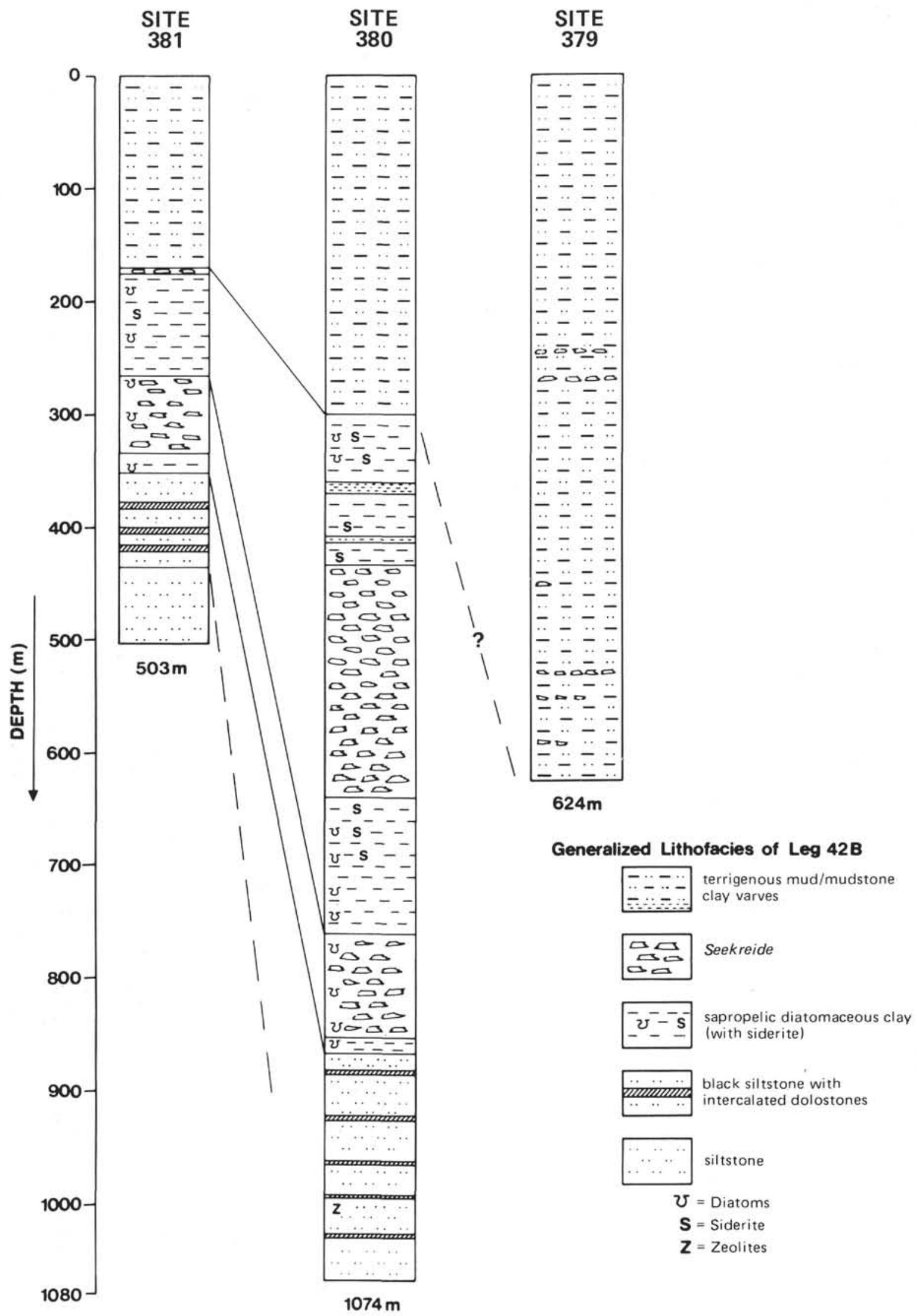

Figure 8. Generalized lithofacies of Leg 42B. 
Carbonate content is less than $20 \%$ and organic carbon is on the order of $0.6 \%$. The detrital carbonate minerals consist of calcite and dolomite. The dolomite is a typical mineral of the terrigenous mud facies. Distinct differences in the mineralogical composition of this facies can be observed between the three sites. In Sites 380 and 381 illite dominates the clay fraction whereas in Hole $379 \mathrm{~A}$ smectite is in general the most abundant clay mineral. The coarse fraction differs in that at 379A rock fragments and feldspar are more frequent. The heavy minerals are distinguished by the occurrence of pyroxene in contrast to the presence of garnet at Sites 380 and 381 . A special type of sediment within the terrigenous muds are the varved brown clays.

In this facies various thin layers of nannofossils, diatoms, sapropels, and marly sediments occur which are distinguished by color changes. In some intervals the monotonous dark greenish gray to dark gray sediments are interrupted by brown to red colored terrigenous sediments.

At Site 381 this terrigenous facies terminates in a medium gray silty sand. The sand is composed of abundant mollusc fragments and well-rounded quartz and feldspar grains (Plate 1, Figure 7). Mica, which is normally common in the sand fraction, was not detected. Figure 9 depicts the textural variations of the terrigenous sediments; most of the samples are concentrated in the silt area. The samples with a high clay content are all from the red and brown sediment intervals.

\section{Seekreide (lake chalk) (Plate 10, Figures 1, 2)}

This facies is distinguished by the presence of authigenic calcite. The carbonate content is in the range of $50 \%$ to $80 \%$ and organic carbon varies between $0.3 \%$ to $1.08 \%$. Because the mineralogy and texture are similar to fine-grained carbonate-rich sediments found in lakes, the term seekreide is used to describe them but it also includes the marly sediments with carbonate contents $<75 \%$. The seekreide is found as thin beds several centimeters thick intercalated in the terrigenous muds or sapropelic clays in Hole 379A, Cores 25, 29,

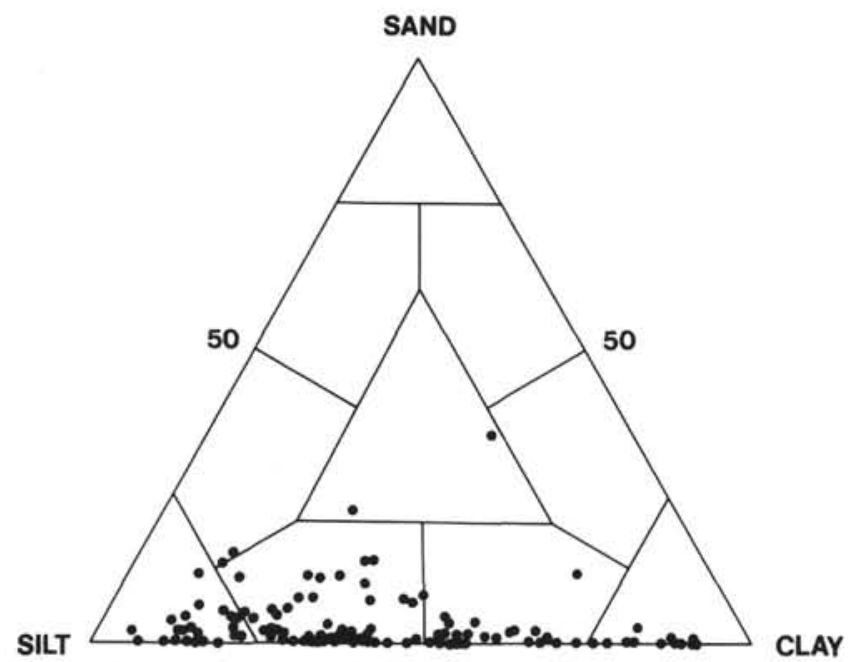

Figure 9. Sand-silt-clay ratios of the terrigenous mud facies.
50, 58, 60, 65; Site 380, Core 39; Hole 380A Cores 1, 9 , $10,60,63$. Larger intervals with abundant seekreide occur in Hole 380A, Cores 12-34, Cores 46-55 and Site 381 , Cores 19, 32-35. The seekreide is either structureless or exhibits a finely laminated varved-type pattern. The structureless variety is often present in a typical rhythmic pattern consisting of an alternating sequence of a thin pyrite layer, dark clay, and seekreide with abundant burrows. The thickness of one cycle is commonly about $4 \mathrm{~cm}$. The laminated varve-like type contains on the order of 20 to 25 varvecouplets per centimeter. Under the scanning microscope most of the calcitic grains exhibit strong corrosion effects (Plate 4). Textural analyses of the seekreide reveal the predominance of silt-sized particles (Figure 10).

Sapropelic Diatomaceous Clay (Plate 1, Figure 3; Plate 5, Figures 1;6; Plate 8, Figures 1-6)

The sapropelic diatomaceous clay facies dominates in Site 380, Cores 32-40, Hole $380 \mathrm{~A}$, Cores 1-12, and 36-46, and Site 381, Cores 22-31 and 35-38. Besides these intervals thin beds are frequently intercalated in other sediment types (e.g., Hole 379A Cores 11, 25, 29).

The facies is distinguished by the presence of aragonite, high-magnesian calcite, siderite, and abundant diatoms. The dominant colors are dark greenish gray to olive-black. Carbonate content is low (except the aragonite laminae) and is in general $<10 \%$. There are certain intervals which are completely carbonate free. The organic carbon content ranges between $1 \%$ and $6 \%$. The aragonite is present in a finely laminated pattern and its content is as high as $80 \%$.

The crystals show a typical wheat or rice grain shape. In some layers aragonite is associated with small amounts of high magnesian calcite. The presence of siderite is indicated by pale olive to light olive-gray colors. It occurs either as spindle-like crystals disseminated in soft sediments or as thin lithified layers and nodules. In this facies Braarudosphaera bigelowi and also a dwarfed benthic Bolivina microfauna is

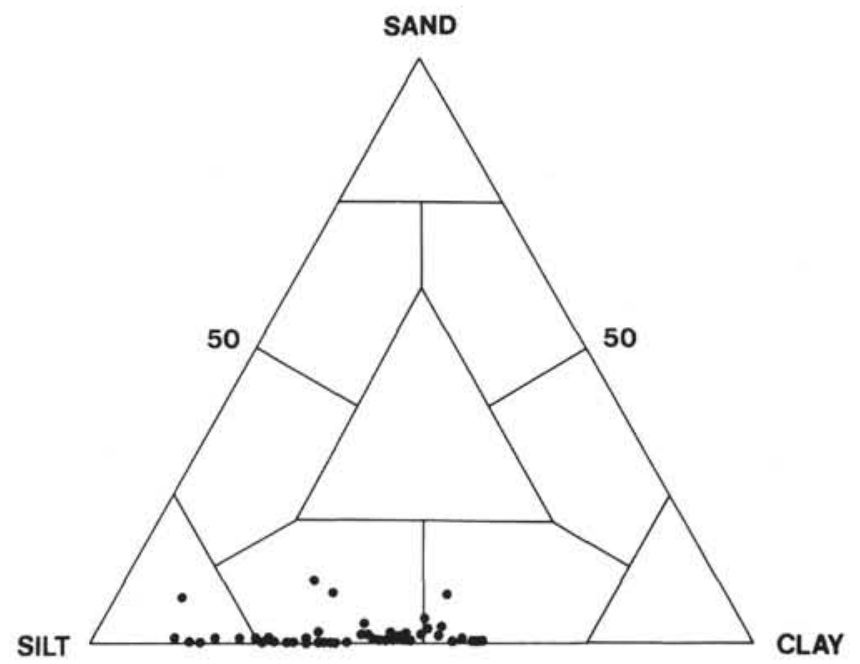

Figure 10. Sand-silt-clay ratios of the seekreide facies. 
found in some intervals (Percival, this volume; Gheorghian, this volume). The diatoms comprise a fresh-brackish as well as marine flora (Schrader, this volume; Jousé, this volume). In many cores of the facies a faint to strong odor of "proto-petroleum" was recognized.

The textural analyses indicate that most of the samples have to be classified as clays to silty clays (Figure 11).

\section{Black Siltstones With Intercalated Dolostones (Plates 10-13)}

This facies is the most unusual lithology encountered in the Black Sea cores. The dominant lithology is a greenish black fissible siltstone. Intercalated in it are brecciated, laminated, or massive dolostones which are typical of the facies. Besides the dolostones, varve-like aragonitic or sometimes calcitic sediments and silty sand layers, which contain abundant zeolites, are present. The facies occurs in Hole 380A, Cores 58-80 and at Site 381, Cores 39-47. At Site 381 recovery of this facies was less than $10 \%$ and only brecciated sediments were noted; these include shell hash, dolomitic rock fragments (including oolitic dolostones), mud, pebbles, and sand. Thin section studies reveal the presence of intraclasts, pellets, crusts, and molds (Plates 10-13). The brecciated sediments are also observed at Hole 380A but only in Core 58. From Core 58 downwards, dolomite occurs as pale olive-gray beds. Pellets as well as intraclasts are also indicated in the thin sections (Plate 13). The black siltstone consists of clay minerals (basically smectite) and up to $20 \%$ quartz and feldspar. Carbonate content is less than $5 \%$. Locally pyrite, volcanic glass, and wood fragments are abundant. Biogenic Constituents are rare or absent. Diatoms were only noted in Cores 60 and 64 of Hole 380A. The textural analyses reveal the silty character of the sediment (Figure 12.)

\section{Siltstone}

This facies is only encountered at Site 381 , Cores 48 54 and consists of an olive-gray to olive-black finely

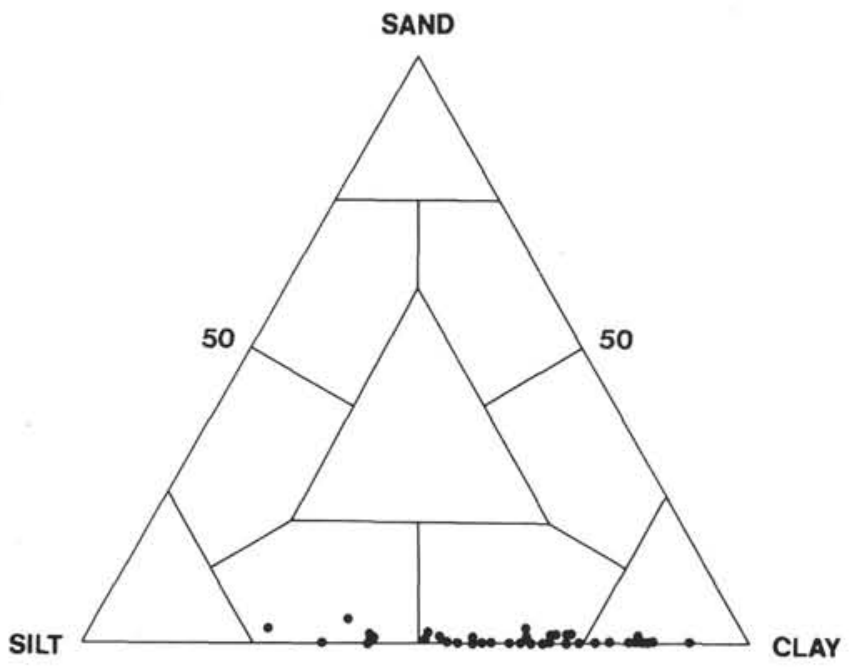

Figure 11. Sand-silt-clay ratios of the sapropelic diatomaceous clay facies.

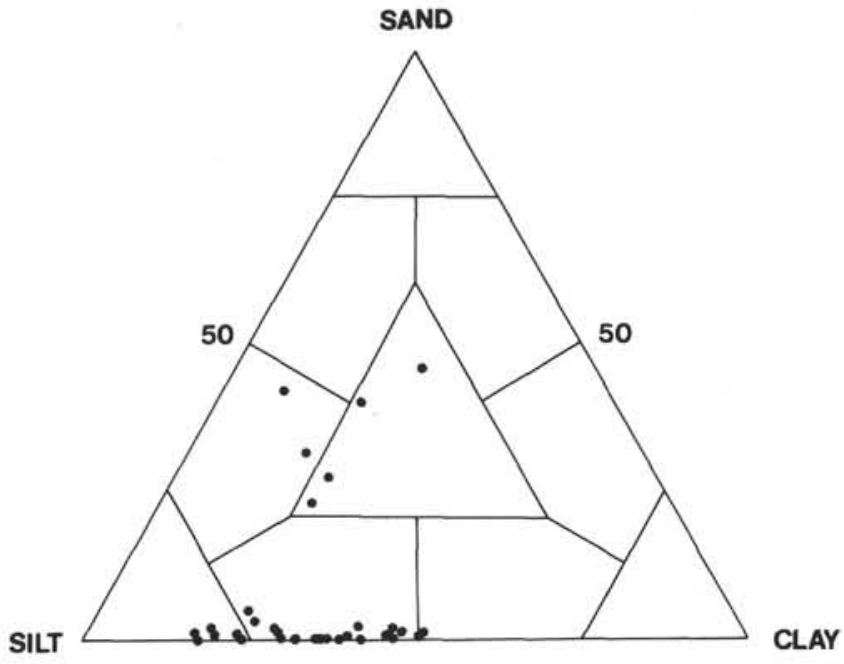

Figure 12. Sand-silt-clay ratios of the black siltstone facies with intercalated dolostone.

laminated siltstone with occasional small bands of siderite. No other carbonates were found in the facies. Within the unit a brecciated interval is present in Core 51. The siltstone is composed of abundant quartz and feldspar ( $>25 \%)$ with the feldspar often higher than the quartz content. The clay fraction is dominated by a well-crystallized smectite with only minor amounts of illite, kaolinite, and chlorite. Hardly any fossil material is reported except diatoms which occur in Core 48. Textural analyses indicate the predominance of siltsized material (Figure 13).

\section{DISCUSSION}

The lower cores from the siltstone facies encountered at Site 381 contain abundant pine-grass-Engelhardia pollen (Traverse, this volume). This vegetation points to a warm climate. The age is most probably late Miocene which makes the facies the oldest cored during Leg 42B. The sediments were deposited in a fresh-water environment as indicated by the diatoms found in Core 48 (Schrader, this volume). The predominance of black

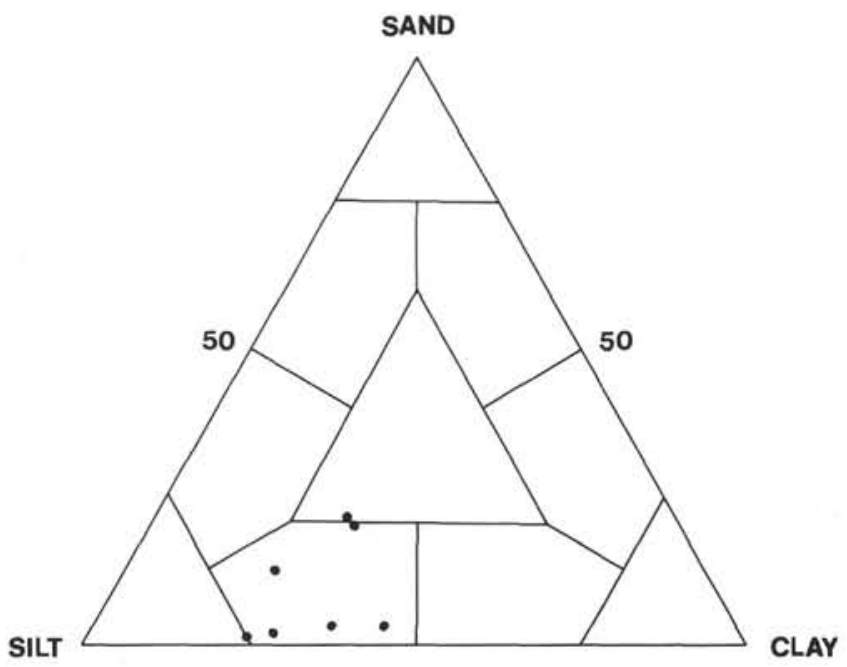

Figure 13. Sand-silt-clay ratios of the siltstone facies. 
to dark greenish colors and the presence of siderite layers suggest reducing conditions. The lamination is preserved due to the absence of burrowing organisms in an oxygen-poor or oxygen-free environment. The breccia found within the dark siltstone consists of abundant light colored clasts which were deposited under oxidizing conditions; the breccia is interpreted as a slump deposit which may have been triggered by some tectonic event. The sediments are basically derived from the south as indicated by the dominance of well-crystallized, smectite (Stoffers and Muller, 1972). The high smectite content found in the clay fraction is caused by the abundance of pyroclastic rocks (including their weathering products) in southwestern Turkey.

The facies is topped by a sequence of siltstones which are distinguished by the presence of dolomite aragonite, high-magnesian calcite, calcite, and zeolite laminae. The sediment color is even darker than that below. Pyrite and organic matter content is high, indicating even stronger reducing conditions. At Site 381 recovery of the facies was very poor and limited to brecciated sediments only. The same kind of breccia was found in Hole $380 \mathrm{~A}$ in the uppermost core of this facies. The presence of volcanic glass and the abundance of smectite give evidence of a nearby volcanic source area. No direct relationship between volcanic glass and the occurrence of zeolites was observed, therefore a volcanic origin of the zeolites seems unlikely. Precipitation from alkaline solutions is assumed.

The environment changed from fresh water to brackish marine as indicated by the presence of small benthic foraminifers. The influx of marine waters into the basin probably caused a density stratification with anoxic conditions below the pycnocline. The black siltstones are practically devoid of carbonates except for distinct carbonate layers which occur periodically. The lack of carbonates in reducing sediments was also observed in recent sediments from the Baltic Sea (Exon, 1972). Carbonates delivered into the anoxic basins are dissolved by $\mathrm{CO}_{2}$ originating from the decay of organic substances within the sediment, whereas in oxic environments which are poor in organic matter carbonates are preserved. The schematic pattern of this carbonate cycle is shown in Figure 14. An oscillating density boundary may be responsible for the recurrence of the carbonate laminae found in the black siltstone. Such oscillations are caused by increased evaporation due to climatic changes. The presence of the individual carbonate layers with high-magnesian calcite, aragonite, or dolomite reflects the $\mathrm{Mg} / \mathrm{Ca}$ ratio of the water and pore water, respectively, in which carbonate precipitation or transformation took place (Muller et al., 1972).

Thin section studies of the intercalated dolostones reveal a great variety of criteria (e.g. intraclasts, algae mats, crusts, pellets, oolites) indicating a shallow environment with occasional subaerial exposure and supratidal-evaporitic conditions. The brecciated sediments of Site 381 especially show abundant evidence of meteoric diagenetic influence. The differences observed in both sites seems to be related to

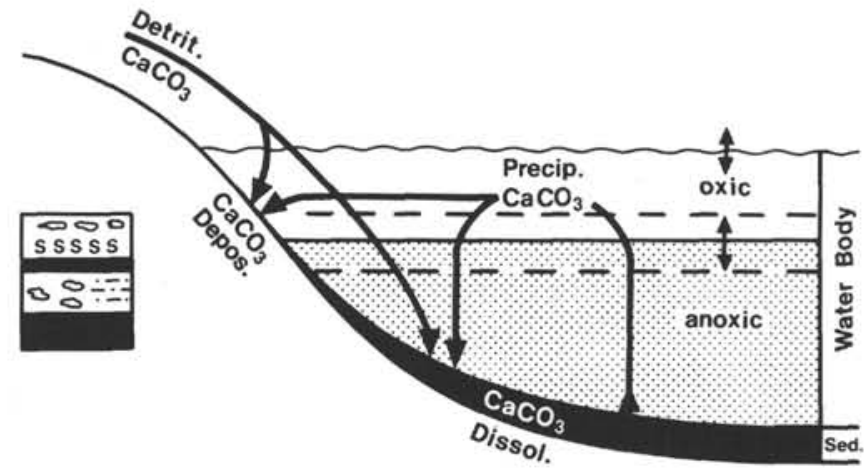

SAPROPELIC MUD

OO MICRITE ( Seekreide)

$\mathrm{s}_{\mathrm{s}} \mathrm{s}$ SIDERITE

$=-:-1$ TERRIGENOUS

Figure 14. Schematic pattern of carbonate deposition and carbonate dissolution.

facies changes caused by the different locations of the two sites (1750 and $2115 \mathrm{~m}$ water depth, respectively). The brecciated dolostone of Site 381 was deposited and altered by early diagenetic processes in an intertidal to supratidal environment whereas, at the same time, Site 380 was covered by shallow water. The presence of the breccia found in the uppermost core of the black siltstone facies in Hole $380 \mathrm{~A}$ might indicate a shoaling of the sea level with a corresponding subaerial exposure and erosion at Site 381. Much of the brecciation at Site 381 may be due to the drilling operation. In Hole $380 \mathrm{~A}$ the breccia seems to be related to a marine influx which rapidly raised the Black Sea water level. The existence of a shallow marine environment below the breccia at Site 380 is supported by the diatom data which suggest a water depth in the range of some meters (Schrader, this volume). The climate was warm as shown by the pollen analysis.

The mineralogical and fossil data clearly indicate that the Pliocene to late Miocene sediments were deposited under shallow water conditions. The sediments could have been deposited either in a preexisting deep basin which was partially desiccated similar to the desiccated deep basin model of the Mediterranean Miocene evaporites (Hsu et al., 1973) or in a shallow basin with a gradual subsidence. A schematic model of the subsidence idea is shown in Figure 15. For the detailed discussion of this question the reader is referred to the specific reports of Hsü; Ross; Paluska and Degens (this volume).

The black siltstone is overlain by an olive-black diatomaceous shale. The sapropelic charactr of the sediment is indicated by the black color and the high amount of organic carbon. Intercalated between the basically carbonate-free shales are laminated carbonates. The cyclic pattern observed is probably caused by an oscillating density boundary as described above. The carbonate laminae are aragonite, with little high-magnesian calcite still reflecting a high $\mathrm{Mg} / \mathrm{Ca}$ 


\section{EVOLUTION OF THE BLACK SEA}
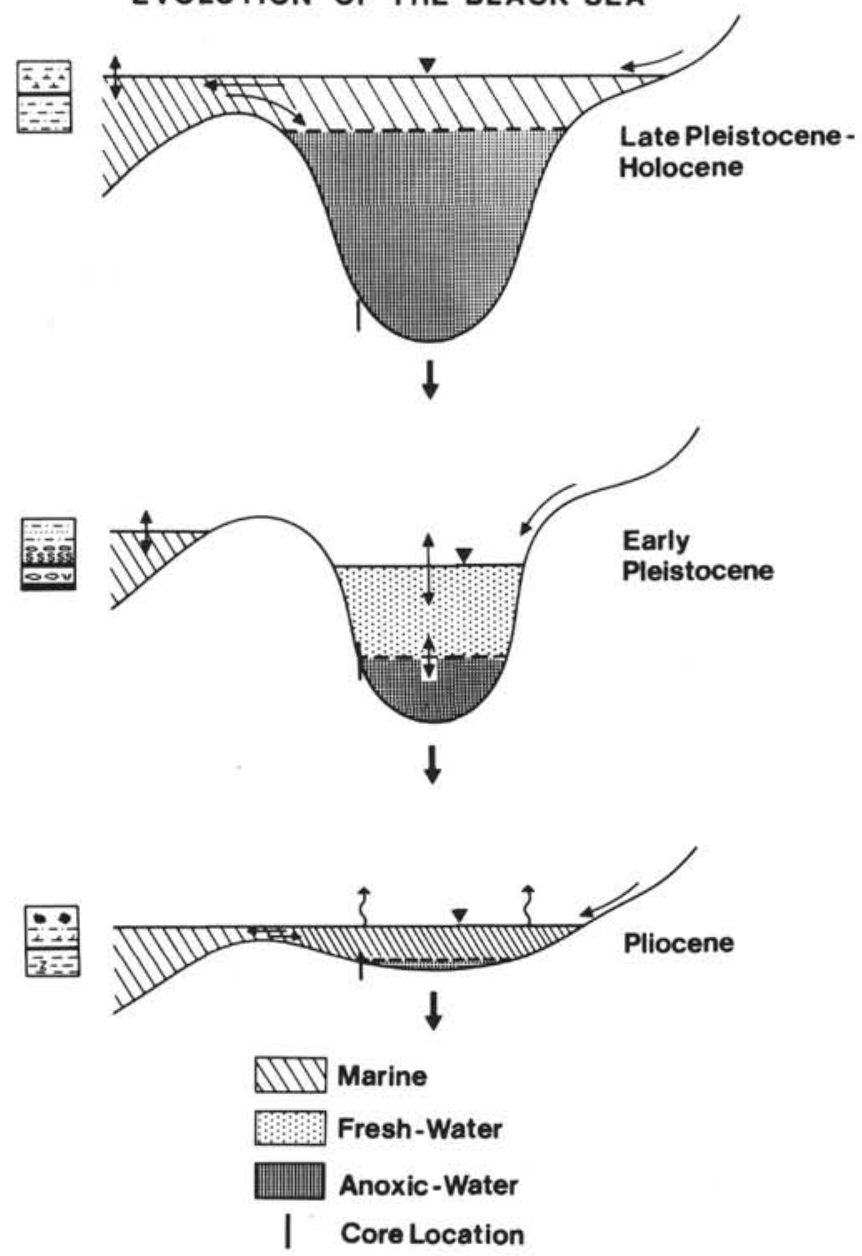

Figure 15. Evolution of the Black Sea under the assumption of Pleistocene subsidence.

ratio of the water. Larger amounts of magnesian calcite which occurred in a slump deposit in Core 57 of Hole $380 \mathrm{~A}$ seemed to be related to biogenic material. The turbated sediments observed in thin sections suggest bottom current activity, probably due to a strong marine influx. The diatoms, the Bolivina microfauna, as well as the presence of Braarudosphaera bigelowi indicate a brackish-marine environment.

In the sapropelic intervals of all three sites a coexistence of aragonite and Braarudosphaera bigelowi was noted. This seems to be a consequence of similar environmental conditions for the formation of aragonite and the optimal living conditions for Braarudosphaera bigelowi which occurs at the lower end of the salinity scale (Bukry, 1974). The sediment contains abundant smectite suggesting that the main sediment transport was still from the south. The climate was warm as shown by the pollen data.

The diatomaceous sapropelic shale facies changed upwards into a diatom-rich seekreide facies. The carbonate material is calcite present mostly in a finely laminated pattern. The laminations are a result of fluctuating concentrations of calcite, terrigenous material, and diatoms and are probably a consequence of seasonal changes. Seasonal diatom blooms cause a depletion of $\mathrm{CO}_{2}$ which favors the precipitation of calcite. The diatoms show evidence of dissolution. Besides the laminated seekreide, beds of structureless marls occur which show abundant burrows indicating sufficient nutrient supply and aeration. The diatoms and the dinoflagellates found in the sediments give evidence of a gradual decrease of the salinity from the base towards the top of this sediment sequence. The environment changed from marine to fresh water. This trend is also reflected in the decrease of the oxygen isotope data towards more negative values (Deuser et. al., this volume). The freshening of the Black Sea caused a decrease in the $\mathrm{Mg} / \mathrm{Ca}$ ratio of the water which is accompanied by a shift in the carbonate mineralogy from aragonite-high-magnesian calcite to calcite. The climate remained warm.

The seekreide is topped by a diatomaceous sapropelic clay again indicating the return to more or less stagnant conditions in the Black Sea. Hardly any reworked coccoliths or detrital carbonates are encountered in this interval which again suggests carbonate dissolution below the interface. The only carbonate mineral present are occasional lithified siderite layers reflecting reducing conditions. Diatom data reveal deposition mainly in a fresh water environment. Some marine influence, however, is suggested by the sporadic occurrence of dinoflagellates. The pollen data point to continuing warm climate.

In the overlying sediments, the facies change back to seekreide deposition. The climate became colder as shown in the pollen spectrum. The temperature decrease and corresponding density increase of the surface water probably led to a breakdown of the stratification and the sedimentation of seekreide. Of the two different types of seekreide present, the structureless beds reveal a cyclic sedimentation pattern consisting of pyrite, mud, and seekreide. They contain abundant chondritic burrows. The cycles are unlikely to be seasonable because this would imply a sedimentation rate in the order of $40 \mathrm{~m} / 1000$ years which does not agree with geothermal considerations (Erickson, this volume). They seem to reflect periodic changes (warmer climate) in connection with a short stratification. Under anoxic conditions the pyrite and the dark mud were deposited. The breakdown of the stratification led to a sufficiently oxygenated bottom and the development of burrowers. The sedimentation rate, however, was presumably too high for the burrowers at the sediment-water interface to produce a completely reworked and mottled sediment texture. In contrast the finely laminated seekreide suggests deposition in the absence of burrowers in an oxygenfree environment. This variety of seekreide is found either as crumbly aggregates or as rhombohedral crystals suggesting different origins. The crumbly aggregates are common in shallow water areas of lakes and originate from reworked carbonate incrustations of submersed aquatic plants and from reworked onkoides (Schäfer, 1973). The crystals, however, might indicate precipitation in surface waters. Hardly any diatoms were noted in this seekreide interval; in particular the laminae variety is devoid of diatoms which may be due either to diatom dissolution or to calcite 
precipitation which took place in the carbonatesaturated surface water. The saturation is caused by a temperature increase with photosynthesis playing only a minor role.

At Site 381 only 2 meters of seekreide were found, whereas at the corresponding interval in Hole $380 \mathrm{~A}$ nearly 200 meters are present. Abundant slump structures occur within the seekreide at Site 380 , and although some of these structures are caused by drilling operations, it seems that part of the material was removed by slumping from Site 381 which is located upslope from Site 380. Cycles of seekreide beds were also described from the lower part of Hole 379A. Whether they can be correlated to the 380/381 seekreide sequence is uncertain.

The ostracode fauna as well as the isotope data favor a fresh-water environment for the facies. The climate was apparently cold with occasional warmer intervals as indicated by the pollen analysis. The association of seekreide with a cold climate is unusual; most deposits of this nature, described from lakes of northern and central Europe, are related to a warm climate, especially the Atlanticum, from Lake Constance, which is distinguished by massive production of seekreide (Staesche, 1972; Schäfer, 1973). The relationship observed in the Black Sea might indicate that supersaturation of calcite was achieved by increased evaporation in a cooler and drier climate.

The seekreide facies is overlain by a sediment sequence consisting of dark clay to clayey silt, siderite and occasional thin carbonte beds; intercalated are varved brown clays. The siderite and dark greenishgray carbonate-free and pyrite-rich mud intervals testify that the Black Sea was again periodically stratified as a consequence of marine water influx. The environment changed from fresh to brackish-marine, as reflected by the presence of marine diatoms and Braarudosphaera bigelowi being associated again with aragonite "wheat grains." The seekreide-rich intercalation indicates an oscillating interface or other environmental changes.

In comparison to the lithified siderite layers noted above, this siderite has a high $\mathrm{Fe} / \mathrm{Mn}$ ratio which difference may be explained by the various source areas: In the lower interval, the sediments are mainly derived from the south where manganese-rich provinces occur in the ophiolites and radiolarites of Western Anatolia (van der Kaaden, personal communication); in the upper siderite interval the influence of the northern distributive province (mainly Danube) predominates.

The laminated brown clays are similar to the lateand post-glacial varved clays described from Swedish lakes (de Geer, 1912). The alternating pale brown and pale olive-gray layers are thought to represent annual depositions, giving a sedimentation rate in the order of 1 to $2 \mathrm{~m} / 1000$ years. Each sediment pair consists of coarser sediments from the spring melt, and finer deposited during later summer and winter. The brownish color suggests oxydizing conditions.

In these sediments a mineralogy different from earlier facies is observed. Illite becomes the most abundant clay mineral, and chlorite, kaolinite and, for the first time, detrital dolomite increase, which points to the influence of a different source area. A northern distributive province is suggested by studies of the Black Sea affluence which have shown that especially the Danube sediments are characterized by the predominance of illite and abundant dolomite (Müller and Stoffers, 1974).

This sediment sequence was probably only encountered at Holes 380/380A.

The lack of material derived from the Danube in the older sediments indicates either that discharge was lower in the late Tertiary or, more likely, that at that time, much of the Danube sediments became trapped in catch basins such as the Pannonian basin. The suddenly increased contribution of terrigenous sediments from the Danube and the other northern rivers in the upper part of the section of the Black Sea signifies that these catch basins probably had become filled and could no longer retain the sediments. This may also explain the large amount of turbidites which occur, especially in the lower part of the terrigenous mud facies. However, the onset of turbiditic sedimentation may also mark a shange in the morphology of the Black Sea such as increased subsidence of the Black Sea which would trigger the beginning of turbidite sedimentation.

At Site 381 the base of the terrigenous facies is a well sorted, rounded to subrounded silty sand composed of abundant mollusc fragments, quartz, and feldspar. These characteristics suggest a beach sand. The sand corresponds to a major unconformity at Site 381 where much of the underlying seekreide is missing.

In the terrigenous facies of Site 379 the higher amount of smectite is related to abundant material having been derived from pyroclastic rocks of the Turkish hinterland. The light colored carbonate-rich sandy silt to silt layers noted in the lower part of Hole 379A (e.g., Core 43) are distinguished by abundant micritic carbonate concretions. They have a different heavy mineral content (opaque, garnet, hornblende) than found in turbiditic sand layers (epidote, hornblende, pyroxene, glaucophane). These light colored silt layers are interpreted as being derived from loess deposits by deflation of periglacial areas. Loess sediments are very common on the Russian platform (Djadtschenko, 1960).

The pollen data of the terrigenous mud facies indicate great climatic fluctuations (Traverse, this volume). Three cold and three warm intervals are recognized which may correspond to the Elsterian, Saalian, and Weichselian glacial stages and the Cromeria, Holsteinian, and Eemian interglacial periods, respectively. During the cold periods no Mediterranean water could enter the Black Sea; the sediments were deposited in a fresh-water environment as demonstrated by the prsence of fresh-water diatoms. Interglacial sea-level rises caused the influx of marine waters over the Bospurus sill permitting the introduction of such organisms as coccolithophorides, foraminifers, and marine diatoms. The change from a fresh to a brackish-marine environment shows the same sequence as described from the Holocene sediments encountered in piston cores. The influx of marine waters into the lake produced a stable density stratification which resulted in the development of anoxic 
conditions and the sedimentation of a sapropel with laminae of aragonite, Braarudosphaera bigelowi, and sometimes siderite. Increasing influx of marine waters led to the deposition of a carbonate mud consisting of abundant coccoliths, such as Emiliania huxleyi or Gephyrocapsa caribbeanica (e.g., Hole 379A, Core 11) (Percival, this volume) and the establishment of environmental conditions as exist today.

\section{ACKNOWLEDGMENTS}

The senior author is indebted to the entire Leg 42B scientific and technical party for their cooperation aboard Glomar Challenger. Special thanks are due to E. T. Degens, K. J. Hsü, D. A. Ross, and H. Schrader for helpful discussions and suggestions. We gratefully acknowledge the support given by the Deutsche Forschungegemeinschaft. We thank G. Krüger and $U$. Kästner for their technical assistance.

\section{REFERENCES}

Andrusov, N. J., 1890. O neobkhodimosti blubokovo dnykh issle dovanii Chernogo morya (Need for deep-water investigations in the Black Sea): Izv. Russk. Geogr. Obsheh., v. 26, p. 171-185.

Arkhangelsky, A. D., 1928. Karra i razrezy osadkov dna Chernogo morya (Map and cross sections of Balck Sea sediments): Hoskov. Obshch. Ispytateley Prirody Byull. Otdel. Geol., v. 6, p. 77-108.

1930. Opolzanie Osadkov na dne Chernogo morya: Geologicheeskoe $\mathrm{z}$ actrenie etogo yavleniya (Slumping sediments on bottom of Black Sea and geological significance of this phenomenon): Moskov, Abshch. Ispytateley Prirody Byull. Otdel. Geol., v. 8, p. 32-79.

Arkhangelsky, A.D. and Strakhov, N.M., 1932. Geologischeskoe istoria Chernogo morya (Geological history of the Black Sea): Moskov. Obshch. Ispytateley Prirody Byull. Otdel. Geol., v. 10, p. 3-104.

Biscaye, P. E., 1965. Mineralogy and sedimentation of Recent deep sea clay in the Atlantic Ocean and adjacent seas and oceans: Geol. Soc. Am. Bull. v. 76, p. 803-832.

Bukry, D., 1974. Coccoliths as paleosalinity indicators-evidence from Black Sea. In Degens, E. T. and Ross, D. A. (Eds.), The Black Sea-Geology, Chemistry, and Biology: Am. Assoc. Petrol. Geol. Mem. 20 , p. $353-363$.

de Geer, G., 1912. A geochronology of the last 12,000 years: C.R. XI Int. Geol. Congr. (Stockholm), v. 1, p. 241-253.

Degens, E. T. and Ross, D. A., 1974. The Black Sea-Geology, chemistry, and biology: Am. Assoc. Petrol. Geol. Mem. 20, p. 633.

Degens, E. T. and Ross, D. A., 1972. Chronology of the Black Sea over the last 25,000 years: Chem. Geol., v. 20, p. $1-16$.

Djadtschenko, M. G., 1960. Uber die Zusammensetzung der Lösse in der Ukraine.-Trudy Inst. Geol. Nauk Ukrain. S.S.R., ser. geomorfol.: tschetwertischn. Geol., v. 1, p. 6869.
Exon, N., 1072. Sedimentation in the outer Flensburg Fjord Area (Baltic Sea) since the last glaciation: Meyniana, v. 22, p. $5-62$.

Hayes, J. B., 1973. Clay petrology of mudstones, Leg 18. In Kulm, L. D., von Huene, R., et al., Initial Reports of the Deep Sea Drilling Project, Volume 18: Washington (U.S. Government Printing Office), p. 903-914.

Hsü, K. J., Cita, H. B., and Ryan, W. B. F., 1973. The origin of the Mediterranean evaporites. In Ryan, W. B. F., Hsü, K. J., et al., Initial Reports of the Deep Sea Drilling Project, Volume 13: Washington (U.S. Government Printing Office), p. 1203.

Matter, A., 1974. Burial diagenesis of pelitic and carbonate deep sea sediments from the Arabian Sea. In Ross, D. A., Whitmarsch, R. B., Weser, O. E., et al., Initial Reports of the Deep Sea Drilling Project, Volume 23: Washington (U.S. Government Printing Office), p. 421-469.

Müller, G. and Gastner, M., 1971. The "Carbonate-Bombe," a simple device for the determination of the carbonate content in sediments, soils and other materials: N. Jb. Mineral., v. 10, p. 466-469.

Muller, G. and Stoffers, P., 1974. Mineralogy and petrology of Black Sea basin sediments, IN Degens, E. T. and Ross, D. A. (Eds.), The Black Sea-geology, chemistry, and biology: Am. Assoc. Petrol. Geol. Mem. 20, p. 200-248.

Müller, G., Irion, G., and Förstner, U., 1972. Formation and diagenesis of inorganic $\mathrm{Ca}-\mathrm{Mg}$ carbonates in the lacustrine environment. Naturwiss., v. 59, p. 158-164.

Schäfer, A., 1973. Zur Entstehung von Seekreide-Untersuchungen am Untersee (Bodensee): N. Jb. Geol. Paläont. Mh., v. 4, p. 216-230.

Staesche, W., 1972 (Diss. Heidelberg). Mineralogischsedimentpetrographische und isotopen-geochemische Untersuchungen an den Kernproben der wissenschaftlichen Bohrungen "Bodensee DFG 1 und 2" im Verlandungsgebiet des Untersees, Bodensee.

Stoffers, P. and Müller, G., 1972. Clay mineralogy of Black Sea sediments: Sedimentology, v. 18, p. 113-121.

Strakhov, N. M., 1954. Osad koo brazovaniyev Chermon more (Sediment formation in the Black Sea), IN Belyankin, D. S. (Ed.), Obrazovaniye osadkov v sovremennykh vodoe makh (Formation of Sediments in contemporary basis): Koskow (Akad. Nauk S.S.S.R. Izd.), p. 81-136.

1961. Oznachenii serovodo vodnogo zarazheniya naddonnoy vodoy basseyna dlya autigenogo mineral cobrazovaniya vego osadkahk-na primere Chernogo meryo (Significance of hydrogen sulfide contamination of water overlying the bottom on formation of authigenic materials in sediments in the Black Sea). In Strakhov, N. M. (Ed.), Sovremennye osadki morey i okeanov (Recent sediments in Seas and oceans): Moskow (Akad. Nauk S.S.S.R. Izd.), p. 521-548.

Zemmels, J., Cook, H. E., and Hathaway, J. C., 1972. X-ray Mineralogy Studies-Leg 11. In Hollister, C. D., Ewing, J. I., et al., Initial Reports of the Deep Sea Drilling Project, Volume 11: Washington (U.S. Government Printing Office), p. 729. 

PLATE 1

Sediments and sediment structures of Black Sea sediments

Figure 1 Hole 380A, Sample 73-2, 10-35 cm.

Zeolite laminae in black silt stone.

Figure 2 Site 381, Section 32-2.

Laminated aragonite interval.

Figure 3 Site 381, Sample 30-2, 70-95 cm. Laminated diatomaceous clay.

Figure 4 Hole 379A, Section 43-5.

Carbonate-rich sandy silt layers intercalated in terrigenous mud. Some layers show ripples and cross-lamination. They are interpreted as loess deposits.

Figure $5 \quad$ Hole 380A, Section 58-1.

Brecciated interval with abundant dolomite clasts and dolomite layers in a siltstone matrix.

Figure 6 Hole 379A, Section 43-5.

Loess sediment; fraction $>63 \mu \mathrm{m}$ consisting of abundant micritic carbonate concretions. Scale bar represents $150 \mu \mathrm{m}$.

Figure 7 Site 381, Section 18-5.

Well-sorted sand consisting of abundant mollusc fragments and subrounded to rounded quartz and feldspar grains (beach sand?) Scale bar represents $0.6 \mathrm{~mm}$.

Figure 8 Hole 380 A, Sample 73-3, 28-36 cm.

Thin section of a sandy layer (quartz, feldspar, clinoptilolite, mica) intercalated in black siltstone. Grading is suggested. Scale bar represents $1 \mathrm{~mm}$. 
PLATE 1
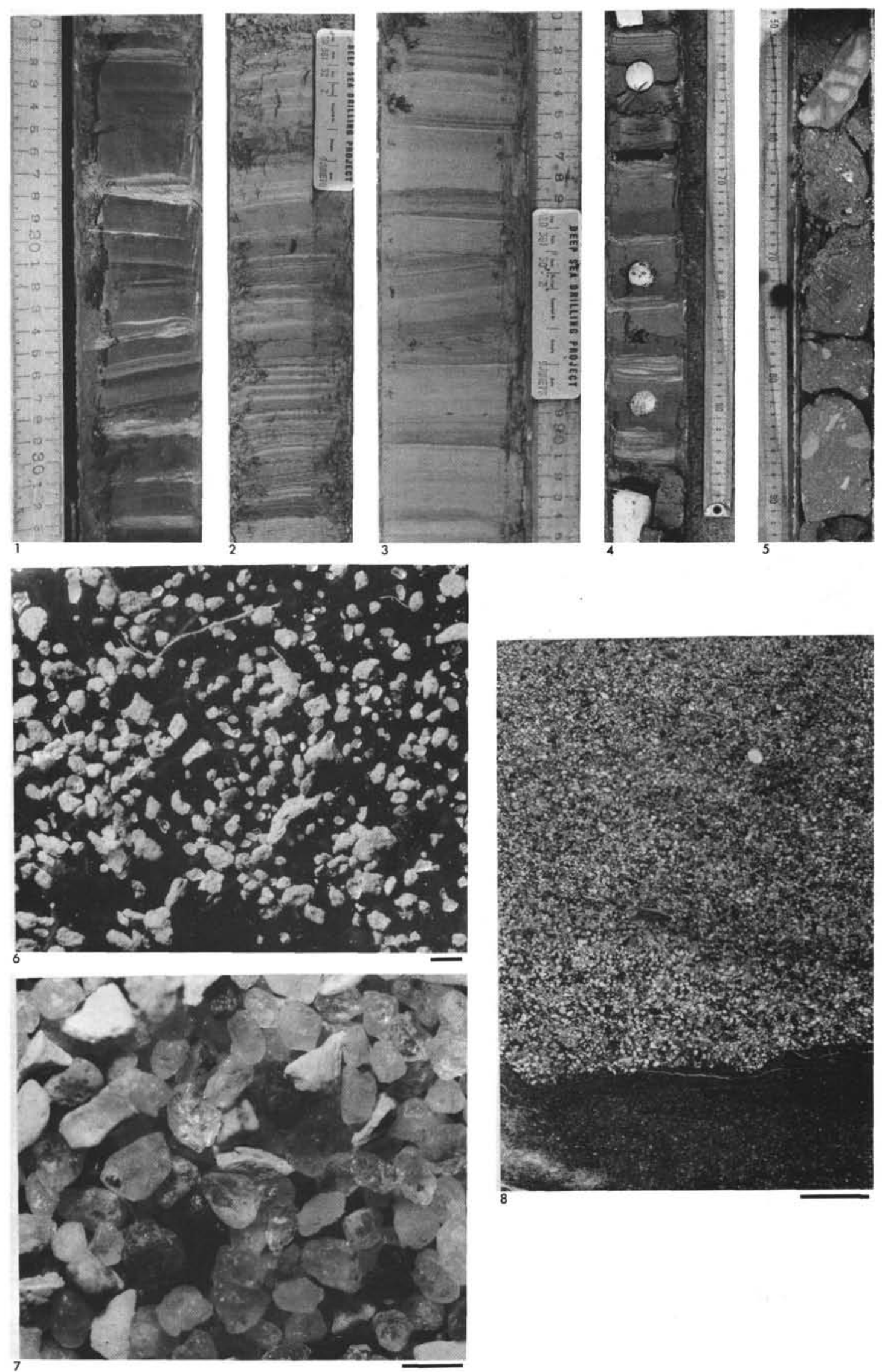
PLATE 2

Biogenic constituents of Black Sea sediments

Figure $1 \quad$ Atlantis II-49-PC 1474.

SEM-picture. Diatoms and aragonitic "rice" grains in the Holocene sapropel layer. Scale bar represents $50 \mu \mathrm{m}$.

Figure 2 Same as Figure 1. Scale bar represents $20 \mu \mathrm{m}$.

Figure 3 Atlantis II-49 PG 1474.

SEM-picture. Coccoliths (Emiliania huxleyi). Scale bar represents $5 \mu \mathrm{m}$.

Figure 4 Same as Figure 3. Scale bar represents $2.5 \mu \mathrm{m}$.

Figure 5 Hole 379A, Sample 9-2, $23 \mathrm{~cm}$.

Smear slide. Dinoflagellates (fresh water).

Scale bar represents $35 \mu \mathrm{m}$, courtesy of $\mathrm{H}$.

Schrader.

Figure 6 Hole 380A, Sample 45-1, $47 \mathrm{~cm}$. Smear slide.

Fresh-water diatoms (Melosira islandica, Melosira

distans, Stephanodiscus triangulatus). Scale bar represents $20 \mu \mathrm{m}$. Courtesy of H. Schrader.

\section{PLATE 3}

Sediments and sediment structures of Black Sea sediments

Figure 1 Hole 379A, Section 11-5.

Sapropel topped by nanno ooze.

Figure 2 Hole 379A, Sample 58-4, 50-75 cm.

Carbonate cycles ("Megavarves") consisting of a thin pyrite layer at the base followed by medium to dark gray mud grading upward into a zone of chondritic burrows. The top is a light gray marl.

Figure 3 Hole 379A, Sample 29-5, 0-25 cm.

Dark laminated sapropel with light gray seekreide intercalations.

Figure 4 Hole 380A, Sample 8-3, 130-150 cm.

Classical varve pattern consisting of alternating pale brown and pale olive-gray laminae; on average there are 4 dark and 4 light layers per $\mathrm{cm}$.

Figure 5 Hole 380A, Sample 31-2, 120-140 cm.

Fine laminates seekreide; on average 25 double varves per centimeter can be counted. Section disturbed by the drilling operation.

Figure 6 Hole 379A, Sample 68-5, 75-100 cm.

Intercalated sand layer in a terrigenous mud section. 
PLATE 2
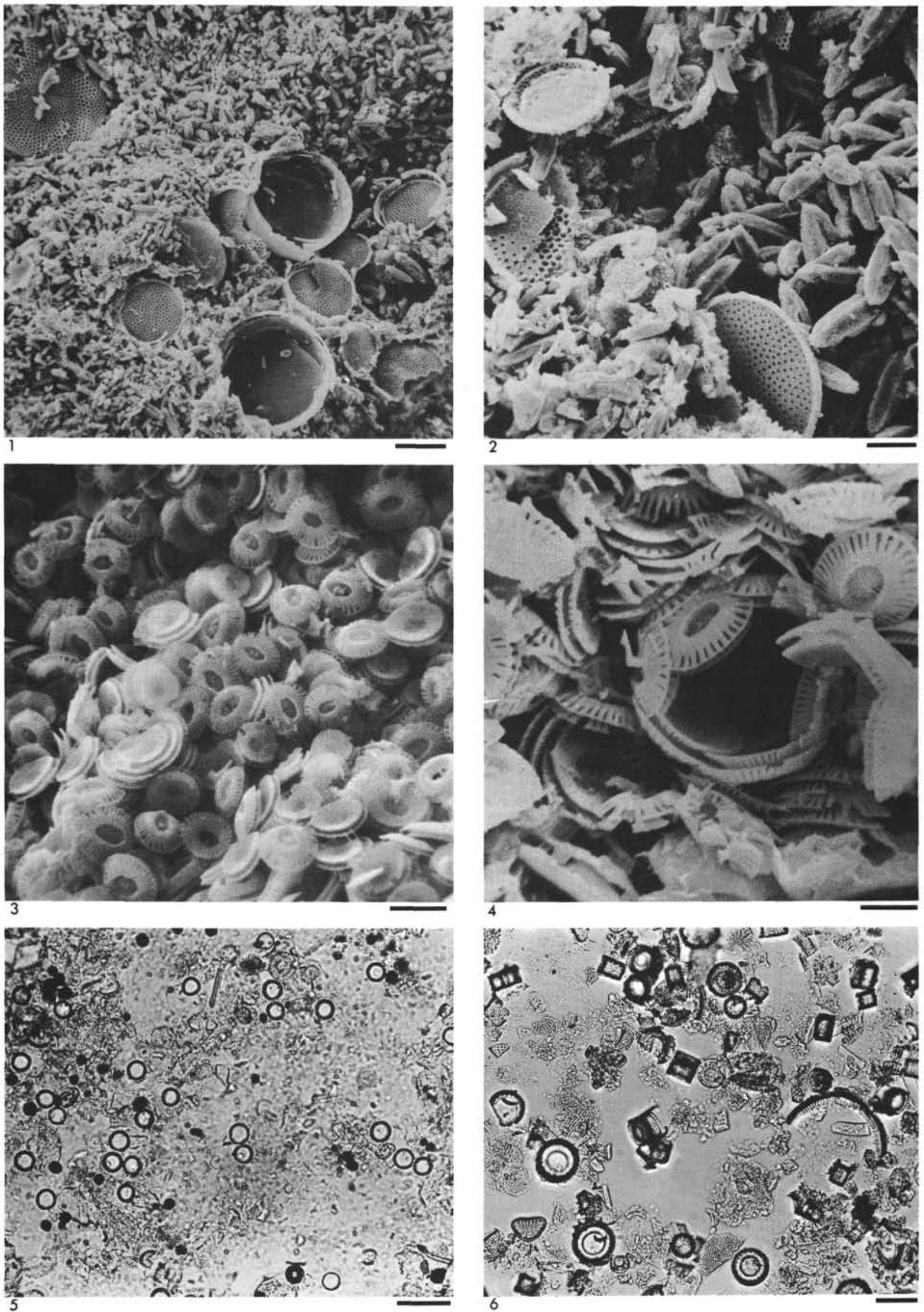


\section{PLATE 3}
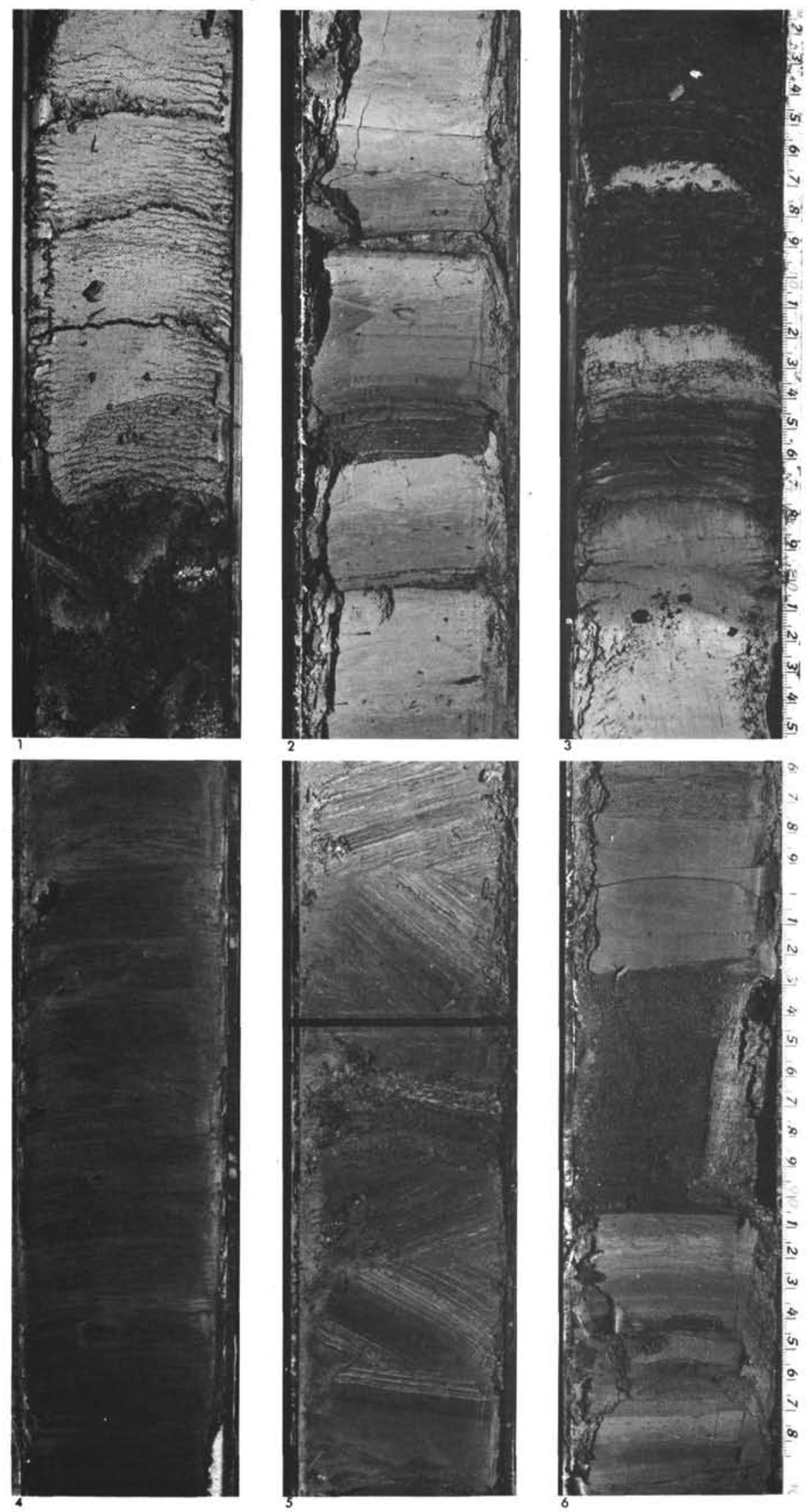


\section{PLATE 4}

SEM pictures of seekreide

Figure 1 Hole 379A, Sample 25-3, 94-95 cm.

Rhomhedral Calcite crystals with corrosion features. Scale bar represents $2 \mu \mathrm{m}$.

Figure 2 Same as Figure 1. Scale bar represents $5 \mu \mathrm{m}$.

Figure 3 Hole 380A, Sample 12-4, 86-88 cm. seekreide. Mostly crumbly aggregates with corrosion features. Some rhombohedral crystals are still present. Scale bar represents $2 \mu \mathrm{m}$.

Figure 4 Same as Figure 3. Scale bar represents $5 \mu \mathrm{m}$.

Figure 5 Hole $380 \mathrm{~A}$, Sample $50-3,12-13 \mathrm{~cm}$.

seekreide with some faint indication of rhombohedral crystals. Scale bar represents $2 \mu \mathrm{m}$.

Figure 6 Hole 379A, Sample 29-4, $142 \mathrm{~cm}$.

Irregular crumbly seekreide aggregates. Scale bar represents $5 \mu \mathrm{m}$.

(see p. 398)

\section{PLATE 5}

Figure 1

Hole 380A, Sample 47-2, 133-135 cm (762.84 m). Varved diatomite-carbonate clay sediment. Length of bar $=0.5 \mathrm{~mm}$.

Figure 2 Hole $380 \mathrm{~A}$, Sample $57-1,119-122 \mathrm{~cm}(856.20 \mathrm{~m})$. Brecciated varved sediment containing abundant aragonite and high-magnesian calcite. Length of bar $=1 \mathrm{~mm}$.

Figure 3 Hole $380 \mathrm{~A}$, Sample $58-1,6-7 \mathrm{~cm}(864.56 \mathrm{~m})$.

Badly sorted laminated mud with abundant lithoclasts, bioclasts, and oolites. Length of bar = $1 \mathrm{~mm}$.

Figure $4 \quad$ Hole $380 \mathrm{~A}$, Sample $58-1,6-7 \mathrm{~cm}(864.56 \mathrm{~m})$.

Same as Figure 3. Length of bar $=0.5 \mathrm{~mm}$.

Figure $5 \quad$ Hole 380 A, Sample 39-3, 98-100 cm $(679.99 \mathrm{~m})$. Fresh-water diatomite layer rich in Melosira sp. Length of bar $=0.1 \mathrm{~mm}$.

Figure $6 \quad$ Hole 380A, Sample 39-3, 98-100 cm $(697.99 \mathrm{~m})$. Melosira sp. in diatomite layer. Length of bar $=$ $0.05 \mathrm{~mm}$.

(see p. 399) 
PLATE 4
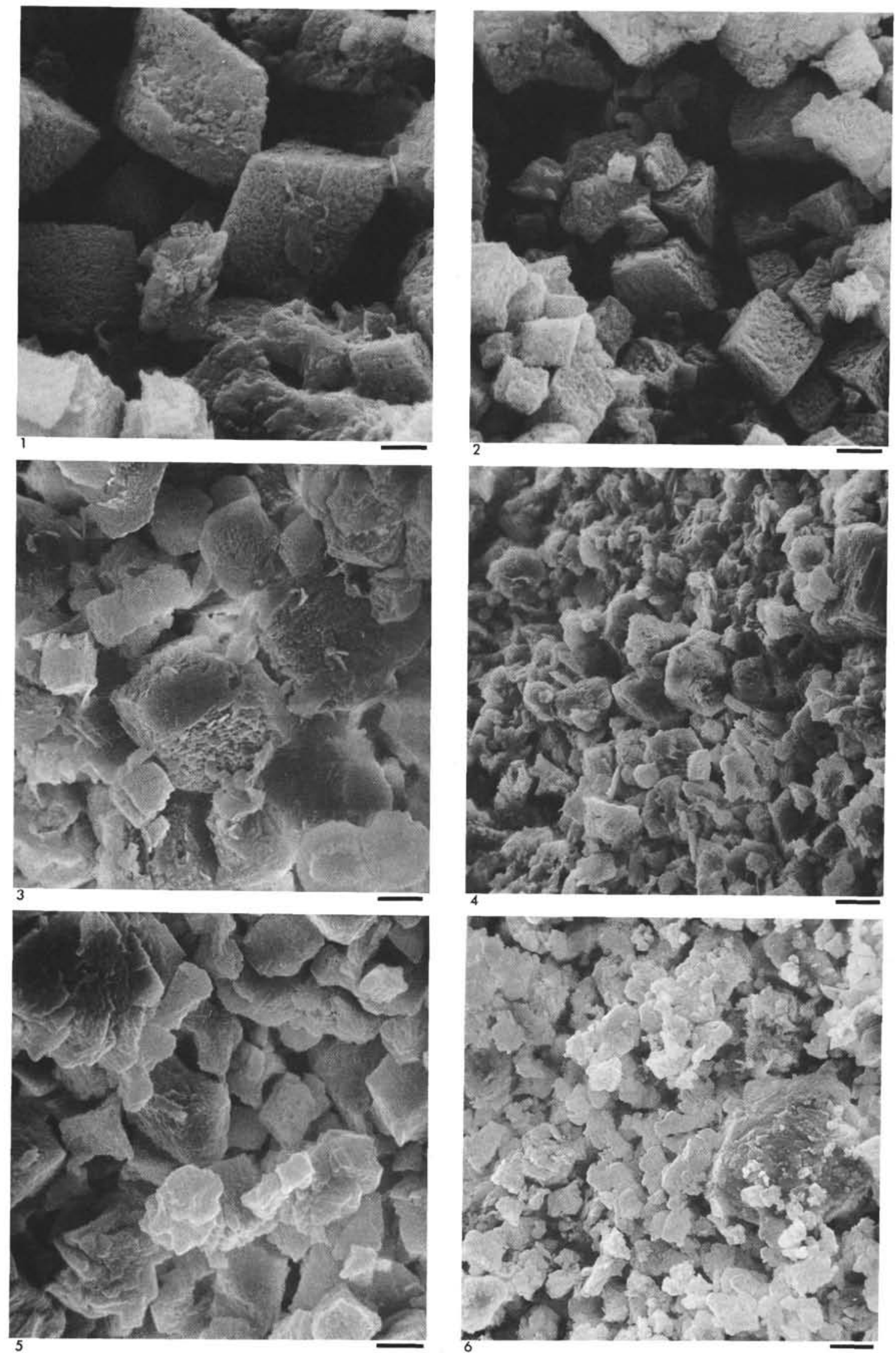


\section{PLATE 5}
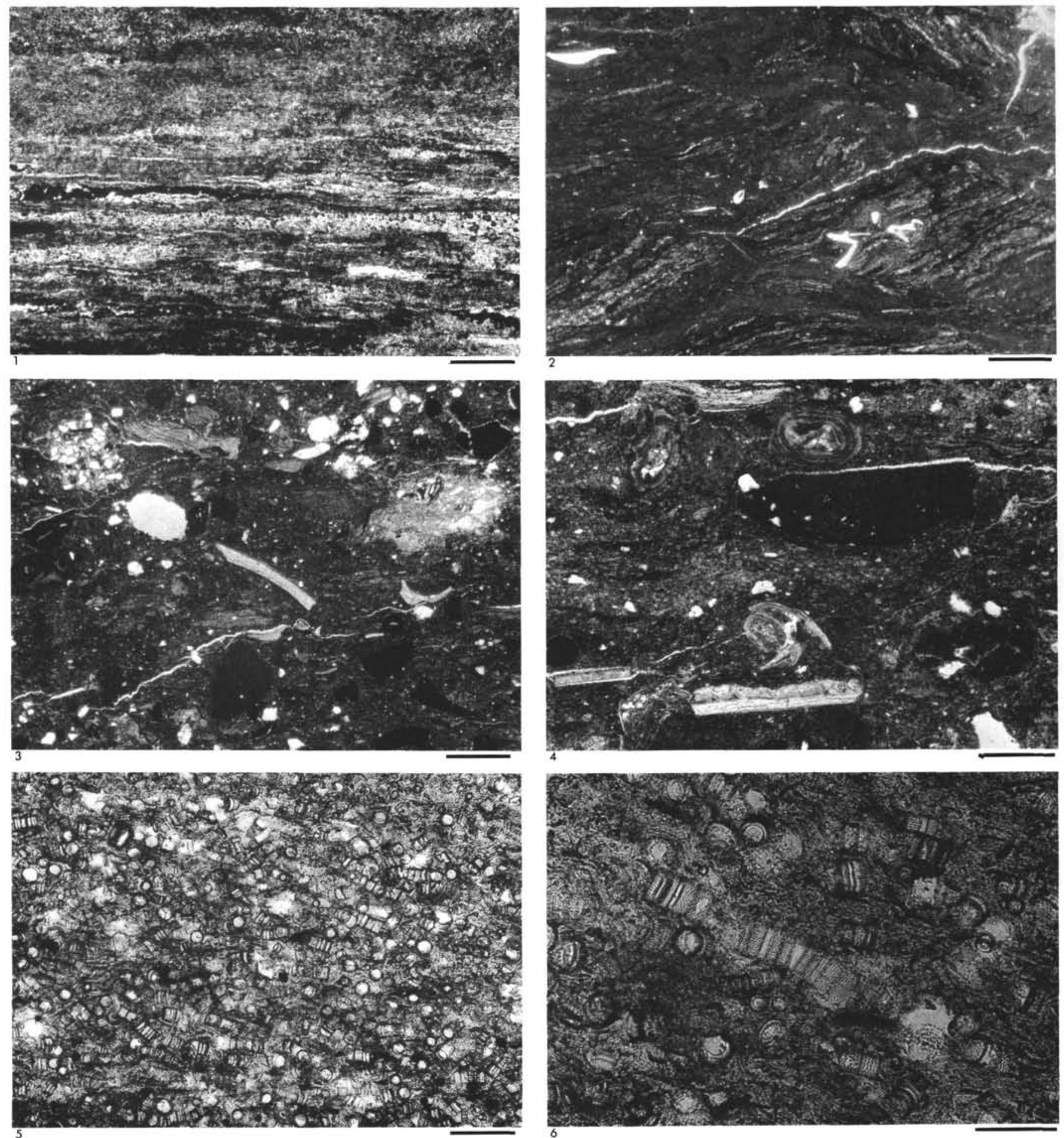


\section{PLATE 6}

SEM pictures of Aragonite in Black Sea sediments

Figure 1 Hole 379A, Sample 11-5, 50-51 cm.

Aragonitic "rice" grains. Scale bar represents 5 $\mu \mathrm{m}$.

Figure 2 Hole 380A, Sample 56-4, 46-47 cm.

Aragonitic "rice" grains with framboidal pyrite. Scale bar represents $2 \mu \mathrm{m}$.

Figure 3 Site 381 , Sample $37-5,45-47 \mathrm{~cm}$. Aragonite twin with corrosion features. Scale bar represents $1 \mu \mathrm{m}$.

Figure 4 Hole 380A, Sample 66-1, 26-28 cm.

Idiomorphic columnar aragonite crystal part of which are composed of a sequence of individual tabular plates. Scale bar represents $5 \mu \mathrm{m}$.

Figure 5 Same as Figure 4. Scale bar represents $6 \mu \mathrm{m}$.

Figure 6 Same as Figure 4. Tabular plates. Scale bar represents $0.5 \mu \mathrm{m}$.

\section{PLATE 7}

SEM pictures of Black Sea sediments

Figures 1, 2 Hole 380A, Sample 73-3, 28-36 cm.

Clinoptililite crystals in coarse-grained material. Scale bar represents $4 \mu \mathrm{m}$.

Figure 3 Hole 380A, Sample 59-1, 145-147 cm. Dolomite. Scale bar represents $2 \mu \mathrm{m}$.

Figure 4 Hole 380A, Sample 72, CC. Dolomite twins. Scale bar represents $5 \mu \mathrm{m}$.

Figure $5 \quad$ Site 381, Sample 23-4, 90-92 cm.

Sideritic sediment. Scale bar represents $5 \mu \mathrm{m}$.

Figure $6 \quad$ Site 380, Sample 39-3, 102-104 cm.

Siderite crystal. Scale bar represents $1 \mu \mathrm{m}$.

(see. p. 402) 


\section{PLATE 6}
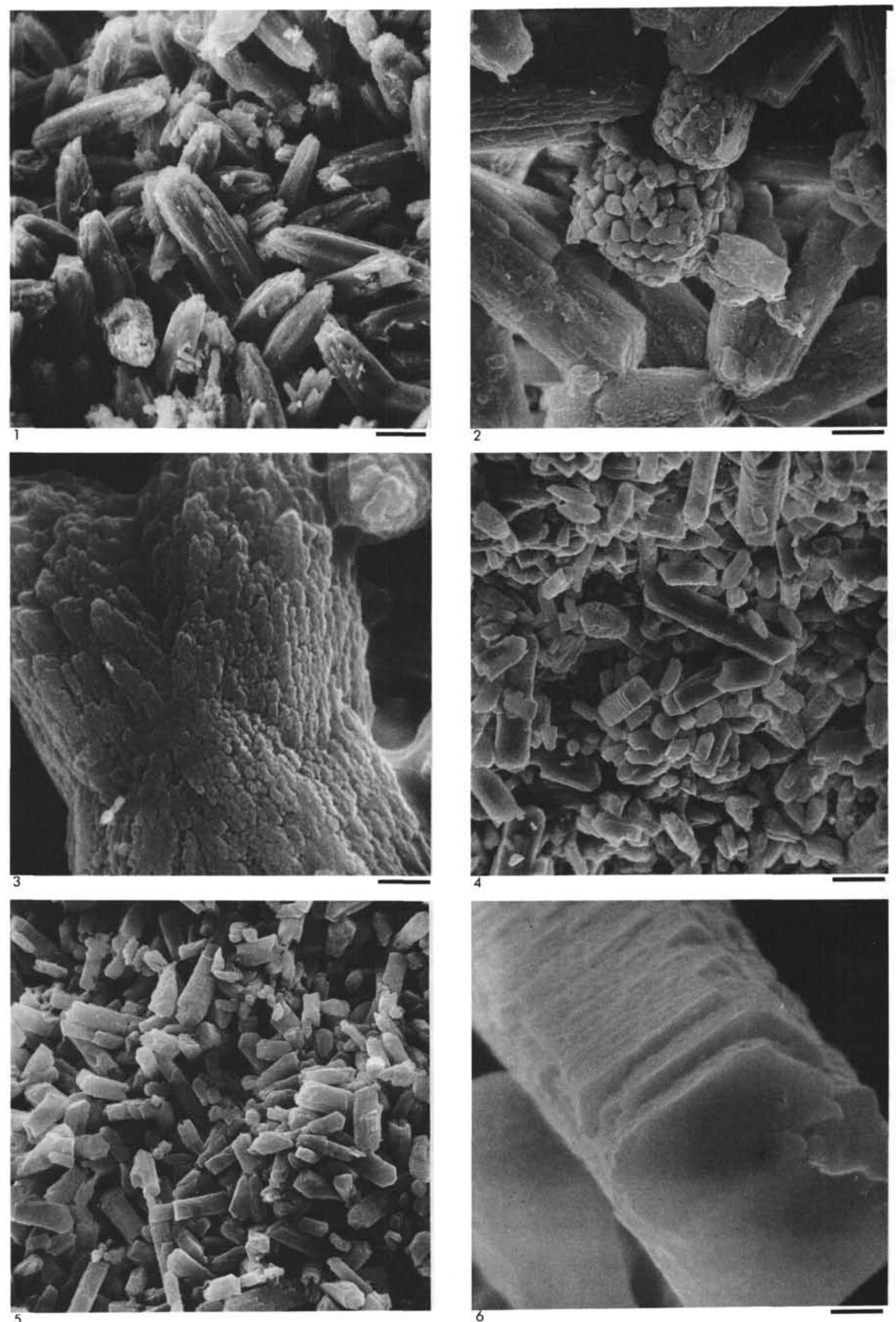
PLATE 7
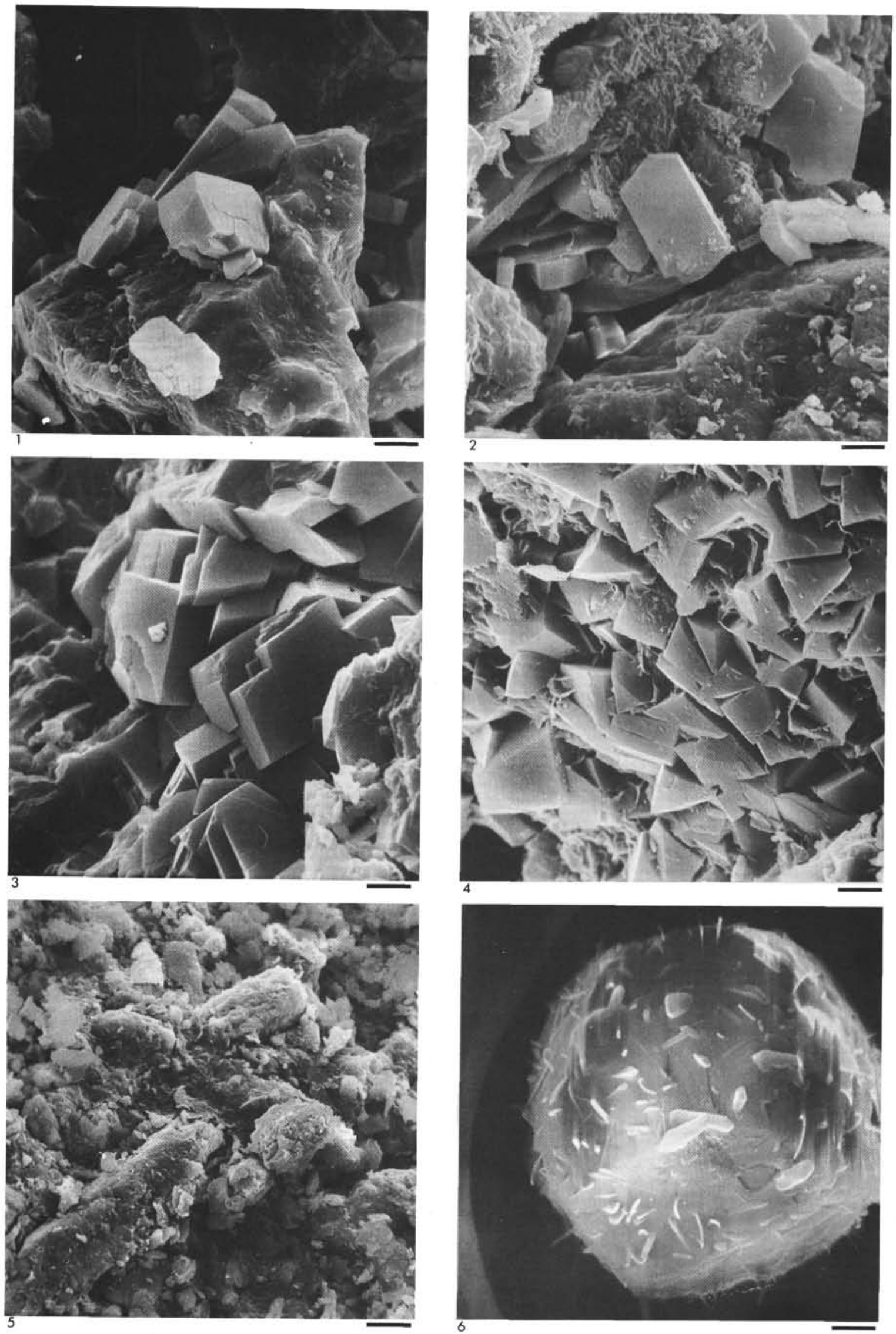
PLATE 8

Siderite layers

Figure $1 \quad$ Hole $380 \mathrm{~A}$, Sample $36-2,80-82 \mathrm{~cm}(657.81 \mathrm{~m})$. Relatively coarse-grained siderite forms on open framework. Length of bar $=0.1 \mathrm{~mm}$.

Figure 2 Hole 380A, Sample 34, CC $(646.00 \mathrm{~m})$. Fine-grained ("micritic") siderite with small pyrite aggregates. Length of bar $=01 . \mathrm{mm}$.

Figure 3 Hole 380A, Sample 40-5, 60-63 cm (701.12 m). Intimately interwoven siderite with small pyrite aggregates. Length of bar $=1 \mathrm{~mm}$.

Figure $4 \quad$ Hole 380A, Sample 40-5, 60-63 cm (701.12 m). Aggregation of framboidal pyrite in siderite. Length of bar $=0.1 \mathrm{~mm}$.

Figure $5 \quad$ Site 381 , Sample $40-1,137 \mathrm{~cm}(362.37 \mathrm{~m})$. Microbrecciated siderite layer. Length of bar $=1$ $\mathrm{mm}$.

Figure $6 \quad$ Site 381 , Sample $40-1,137 \mathrm{~cm}(362.37 \mathrm{~m})$. Microbrecciated siderite layer (more strongly enlarged). Length of bar $=0.5 \mathrm{~m}$.

(see p. 404)

\section{PLATE 9}

Seekreide (Figures 1,2) and terrigenous mud facies

(Figures 3-6)

Figure 1 Hole $380 \mathrm{~A}$, Sample $49-15,142-44 \mathrm{~cm}(785.43 \mathrm{~m})$. Seekreide with cloudy nodular texture. Length of bar $=0.5 \mathrm{~mm}$.

Figure 2 Hole 380A, Sample 22-6, 68-70 cm (540.19 m). Homogeneous seekreide. Length of bar $=0.5$ $\mathrm{mm}$.

Figure 3 Site 380 , Sample 18-6, 66-68 cm (169.67 m). Silt-sized mud, weakly stratified. Length of bar $=$ $0.5 \mathrm{~mm}$.

Figure 4 Hole 379A, Sample 22-4, 110-112 cm (202.61 m). Silt-sized mud, darker laminae rich in organic matter. Length of bar $=0.5 \mathrm{~mm}$.

Figure 5 Hole 379A, Sample 58-4, 87-96 cm (534.92 m). Fine sand in muddy sequence. Length of bar $=1$ $\mathrm{mm}$.

Figure 6 Hole 379A, Sample 58-4, 87-96 cm (534.92 m). Sand layer with graded bedding overlies silt-sized mud. Length of bar $=0.5 \mathrm{~mm}$. 
PLATE 8
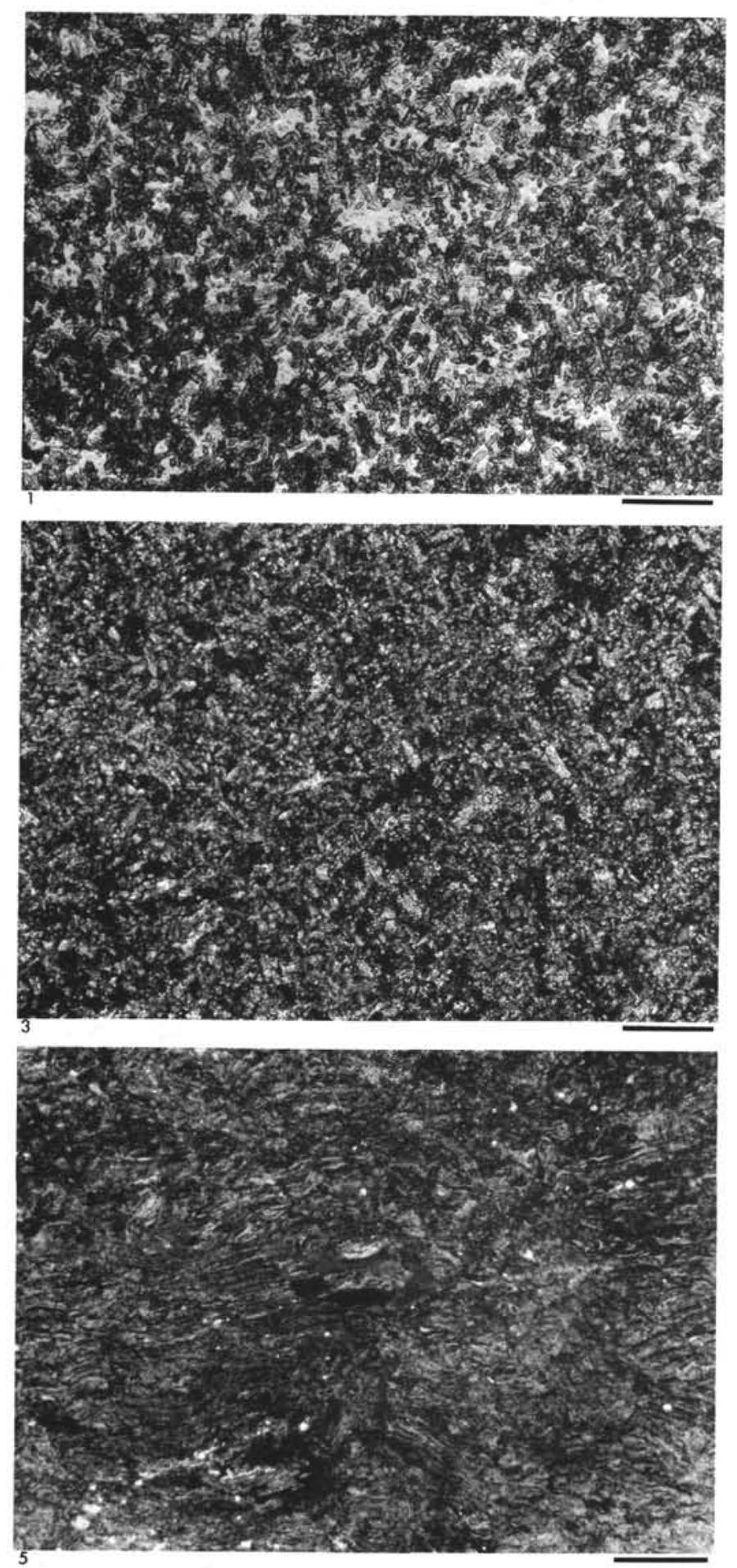
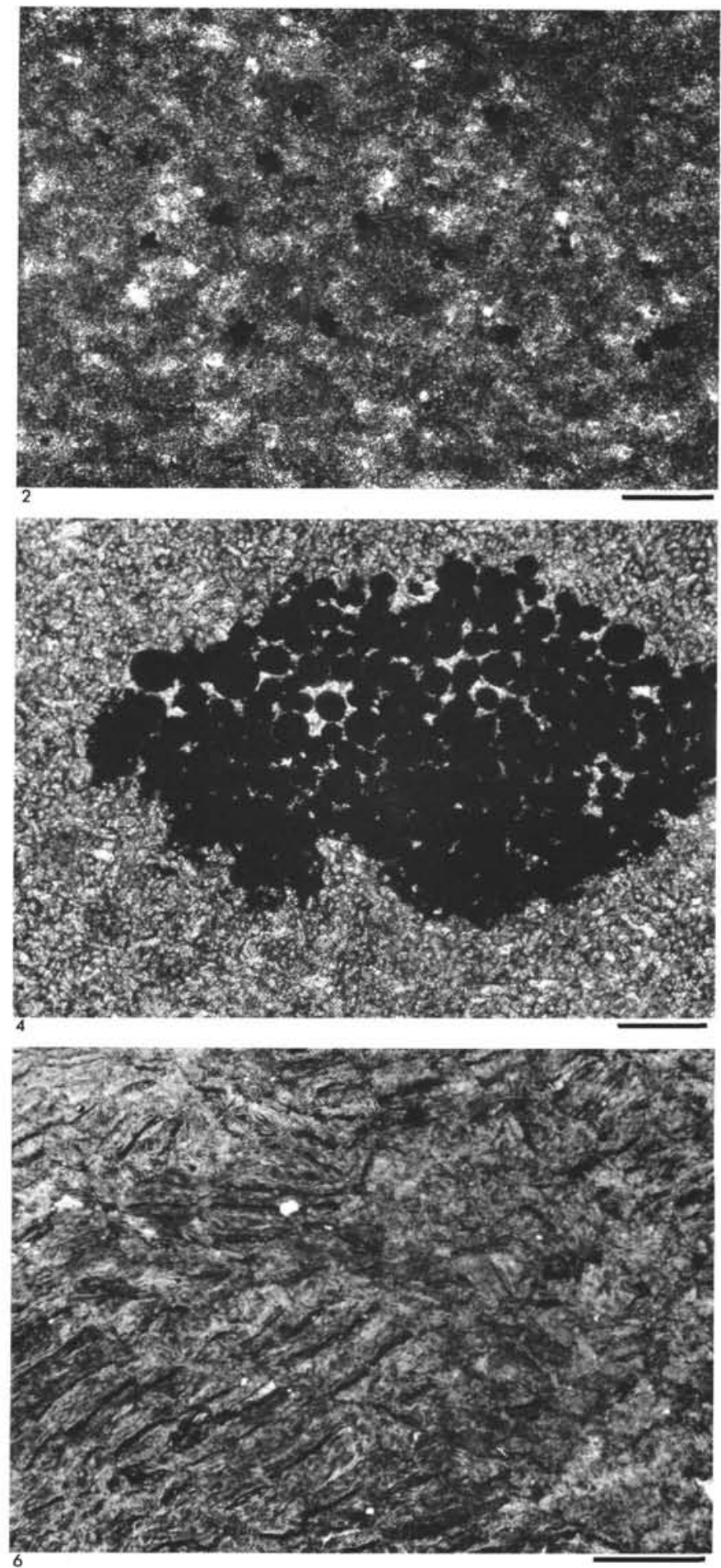
PLATE 9
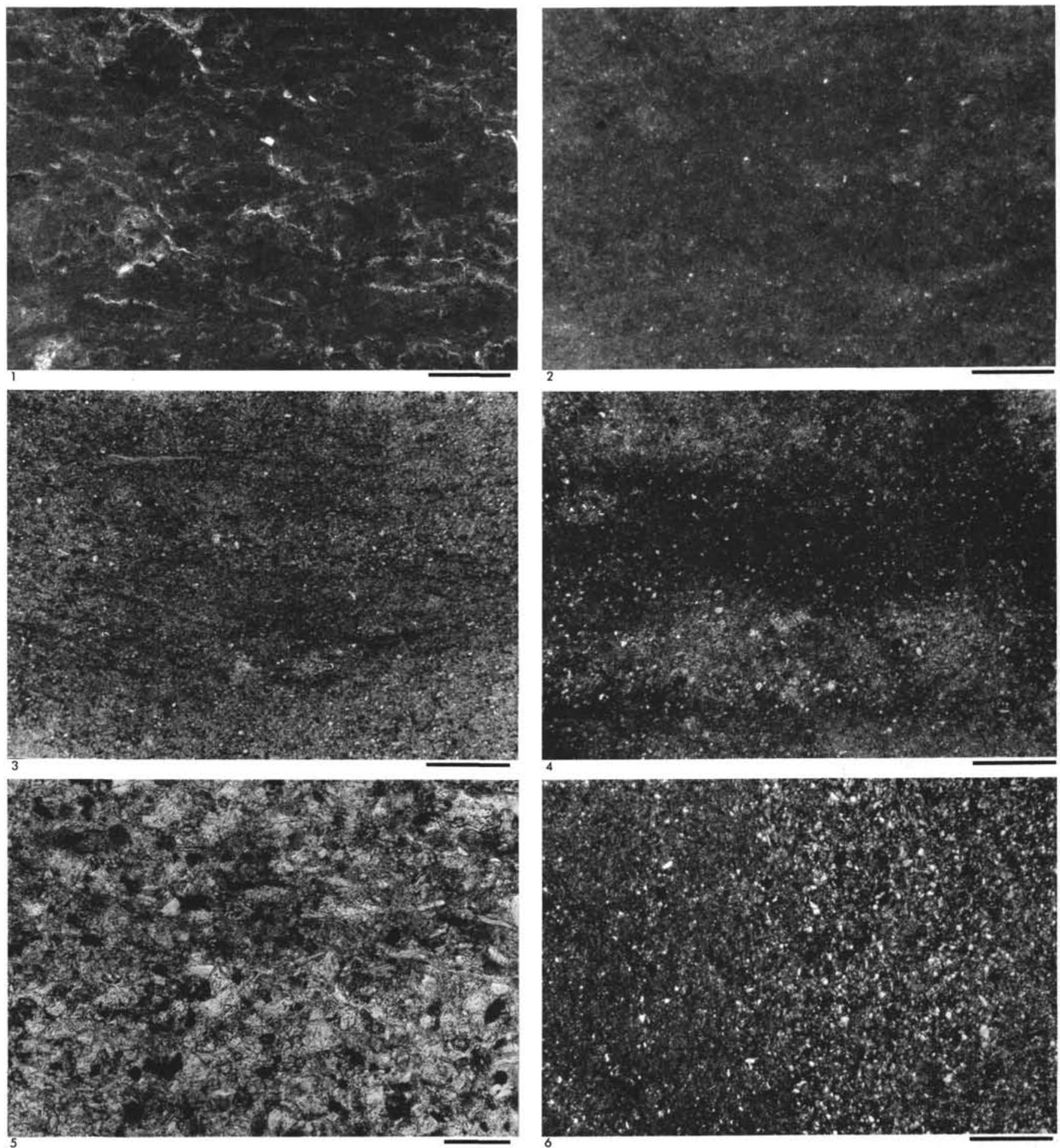
PLATE 10

Dolomitic Oosparites with high moldic porosity

This rock type consists of calcitic oolites (partly dissolved) and lesser calcitic clasts which are cemented by an even rim dolomite cement. The following diagenetic stages are assumed:

I Cementation of oolites and clasts with probably highmagnesian calcite in the subtidal or intertidal environment ("beach rock").

II Dolomitization of the high-magnesian cement in the supratidalevaporitic environment by solutions with a strongly elevated $\mathrm{Mg} / \mathrm{Ca}$ ratio.

III Dissolution of most of the oolite aragonite under meteoric condition (vadose hydrologic zone) with creation of high moldic porosity.

Figures 1-4 Site 381, Sample 39-1, $45-47 \mathrm{~cm}(351.9 \mathrm{~m})$.

1, 2. Length of bar $=0.5 \mathrm{~mm}$.

3 , 4. Length of bar $=0.1 \mathrm{~mm}$.

Figures 5, 6 Site 381, Sample 39-1, 135-137 cm (352.8 m).

Length of bar $=0.1 \mathrm{~mm}$.

2,4 and $6: \times$ nichols.

PLATE 11

Dolomitic crusts

Figure 1 Hole 380A, Sample 59-1, 25-27 cm (874.26 m).

Dolomitic crust with pelletoidal intraclasts and partly carbonate filled vugs. Length of bar $=3$ $\mathrm{mm}$.

Figure 2 Hole 380 A, Sample 59-1, 25-27 cm (874.26 m).

Section of Figure 1 dolomite fills vug partly. Length of bar $=1 \mathrm{~mm}, \times$ nichols.

Figure 3 Site 381, Sample 42, CC $(389.50 \mathrm{~m})$.

Dolomitic crust (pelletoidal dolostone) with vugs evenly coaled with sparry dolomite cement. Length of bar $=0.5 \mathrm{~mm}$.

Figure 4 Same as Figure 3, $\times$ nichols. Length of bar $=0.3$ $\mathrm{mm}$.

Figure 5 Recent dolomitic crust from the supratidalevaporitic environment of Williams. Island, Bahamas. Length of bar $=0.5 \mathrm{~mm}$.

Figure 6 Same as Figure 5, $\times$ nichols. Length of bar $=0.5$ $\mathrm{mm}$. 

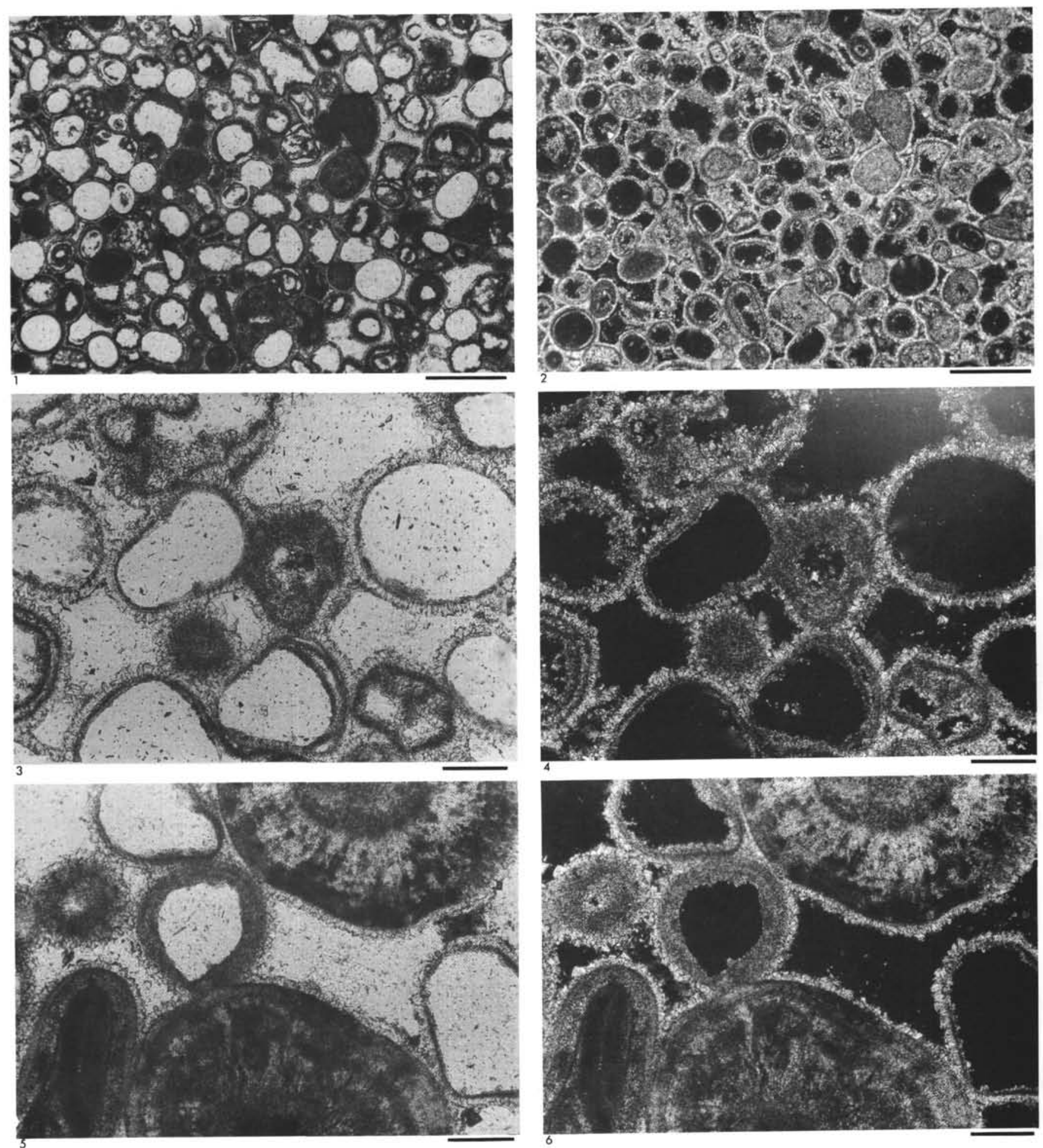
PLATE 11
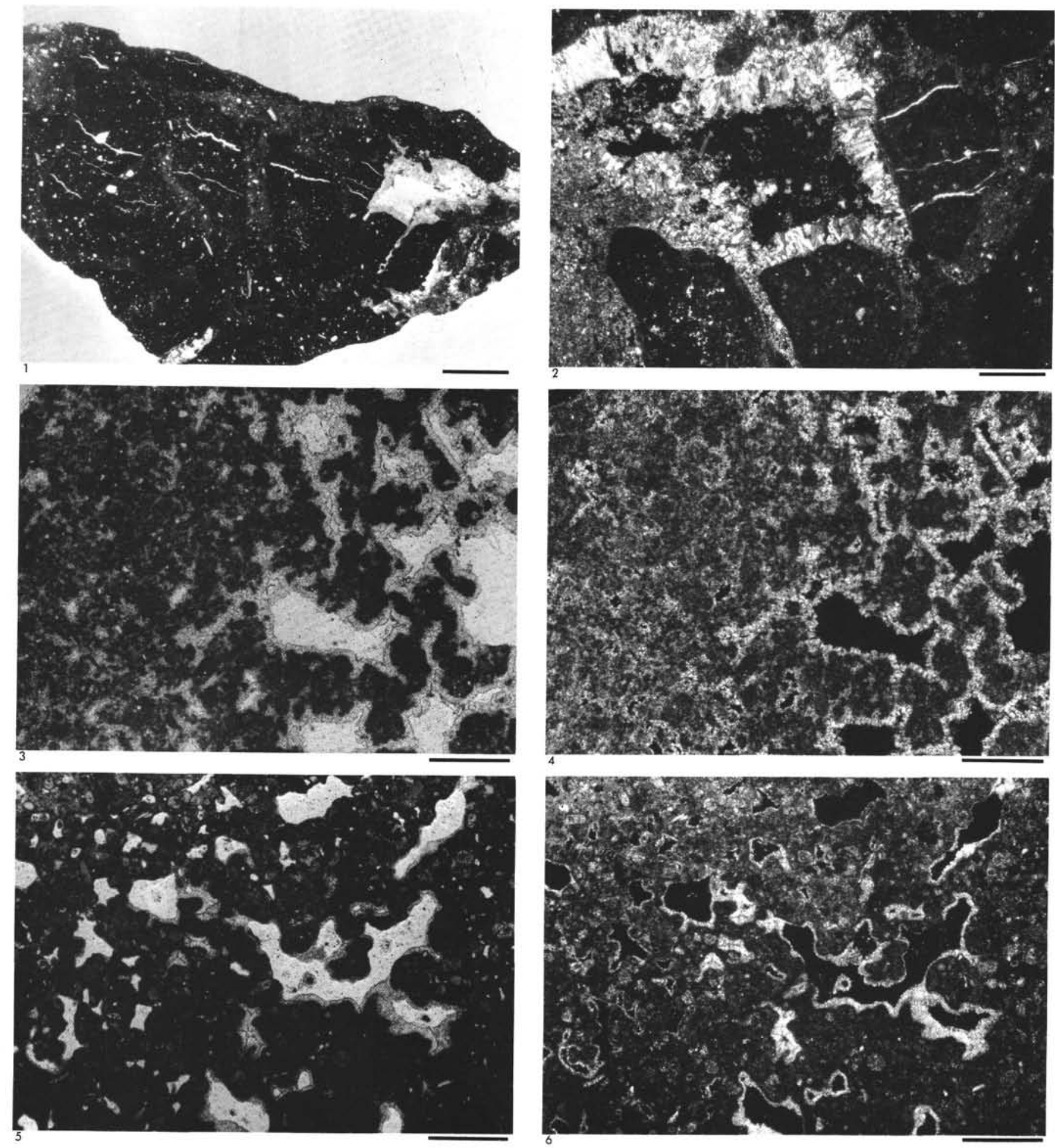


\section{PLATE 12}

Figures 1, 3-6 Site 381, Sample 46, CC (427.5 m).

Dolomitic calcarenite rich in quartz and feldspars. Main allochems are fragments of micritic dolostone (origin uncertain), mollusc fragments (5), oolites (6), and (very rare) algal onkolite $(3,5)$. Detritic quartz and feldspar is very abundant. Allochems and grains are cemented with an evenrim cement (cement A); further pore filling with microsparitic cement (cement B).

The moldic porosity in the bioclast (5) indicates a dissolution of the original aragonite under meteoric conditions, a partial filling of the mold with calcite which, together with the original carbonate composition of the allochems plus the carbonate cement was altered into dolomite in a probably meteoric-evaporitic stage. All figures $\times$ nichols.

Figure 2 Hole 380A, Sample 57-1, 65-67 cm (855.66 m). Quartz-sandstone, calcite cemented with calcitic clasts and bioclasts (shell fragments and benthic foraminifers). Cementation probably occurred under meteoric conditions.

Length of $\mathrm{bar}=1,3=0.5 \mathrm{~mm} ; 2,4-6=0.1 \mathrm{~mm}$.

(see p. 410)

\section{PLATE 13}

Figure 1 Hole 380A, Sample 66-1, 21-22 cm (940.71 m). Laminated aragonitic siltstone with microflaser bedding. Length of bar $=0.5 \mathrm{~mm}$.

Figure 2 Hole 380A, Sample 66-1, 21-22 cm (940.71 m), Laminated aragonite siltstone with volcanic glass particle. Length of bar $=0.5 \mathrm{~mm}$.

Figure 3 Hole 380A, Sample 79-1, 100-106 cm (1065.03 m). Laminated microsparitic dolostones (very probably fossil algae mat). Length of bar $=0.1$ $\mathrm{mm}$.

Figure 4 Hole 380A, Sample 63-2, 114-119 cm (914.5 m). Pelletoidal dolostone, probably pelmicrite dolomitized in a supratidal-evaporitic environment and further cementation with meteoric calcite. Length of bar $=0.5 \mathrm{~mm}$.

Figure 5 Hole $380 \mathrm{~A}$, Sample $59-1,145-147 \mathrm{~cm}(857.46 \mathrm{~m})$. Intramicrite/pelmicrite. Length of bar $=0.5 \mathrm{~mm}$.

Figure 6 Site 381, Sample 39-1, 39-41 cm (351.91 m). Pelmicrite with oolites (?) intraclasts and some bioclasts. Cementation and dolomitization probably in the supratidal-evaporitic environment. Length of bar $=0.5 \mathrm{~mm}, \times$ nichols. 


\section{PLATE 12}
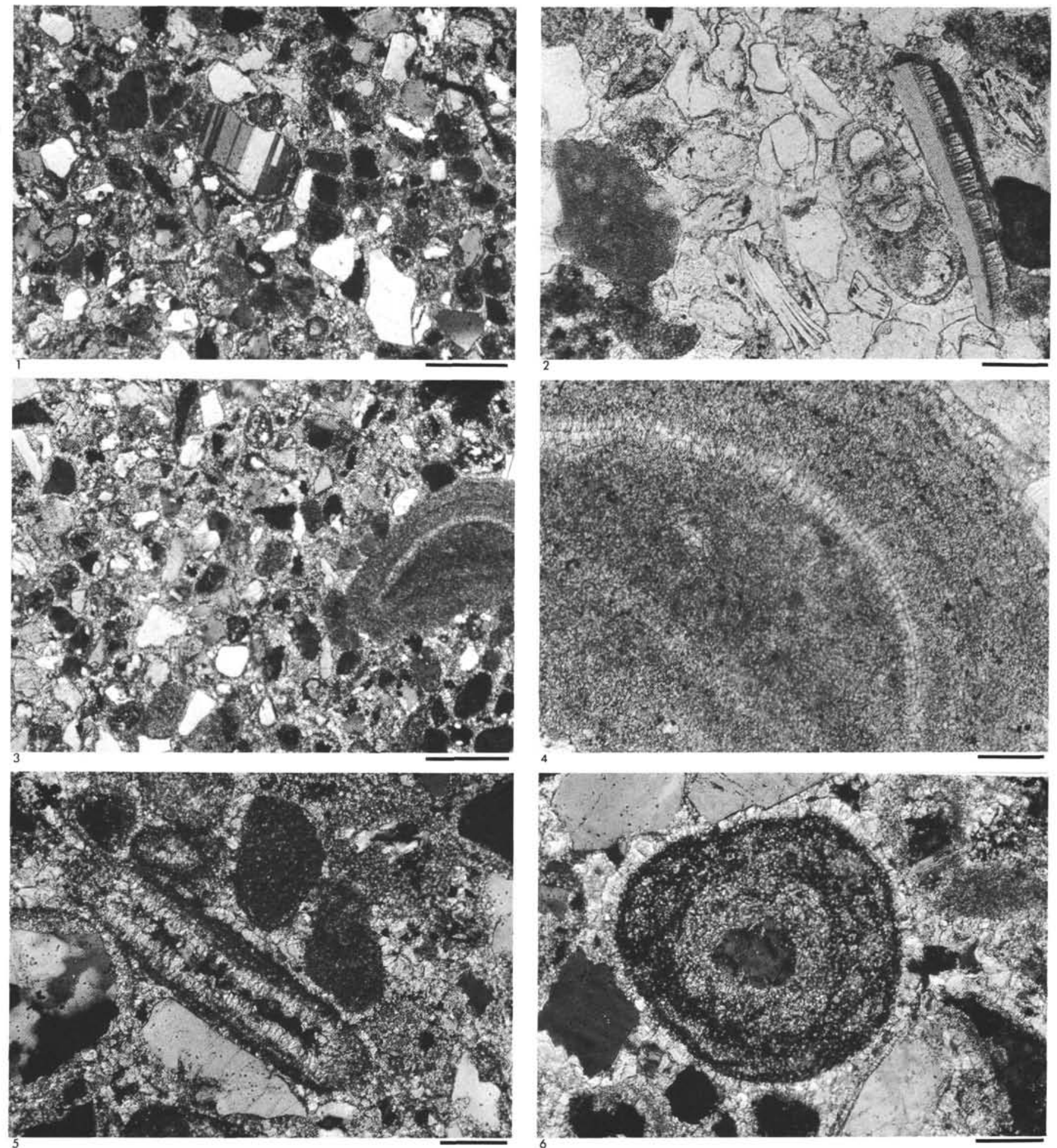


\section{PLATE 13}
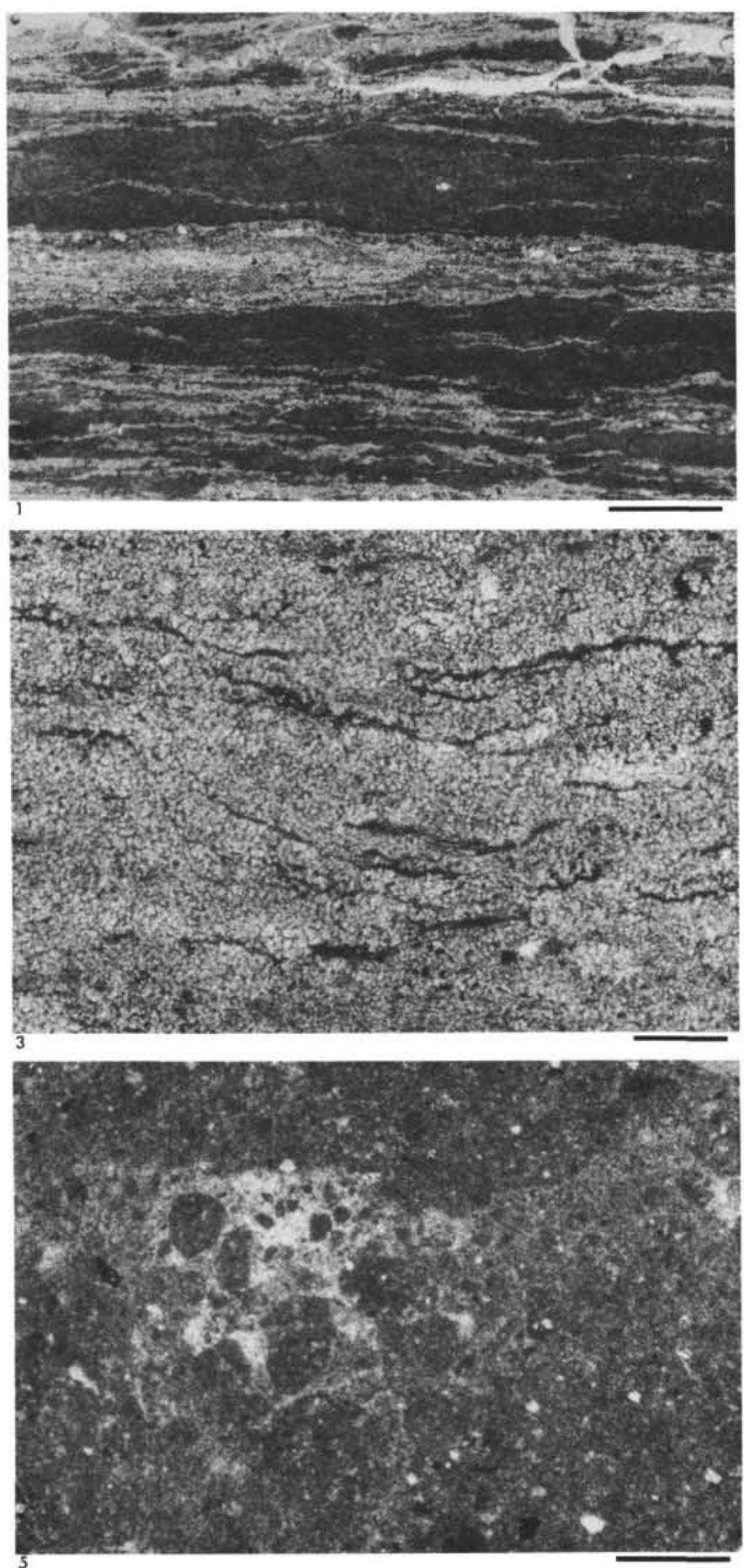

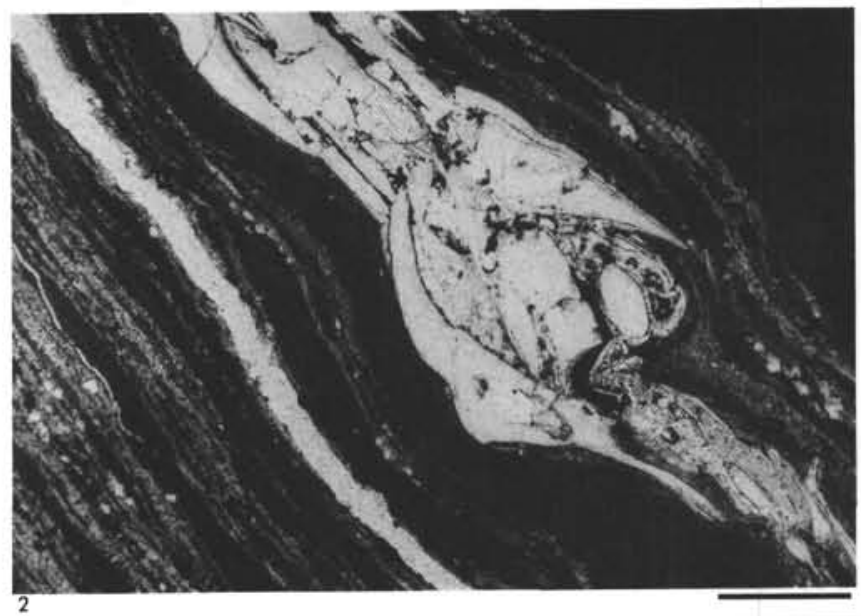

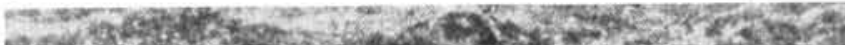
esplety on

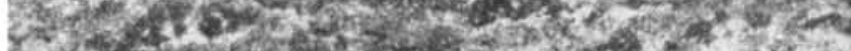

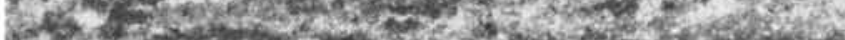

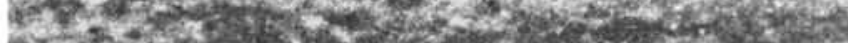

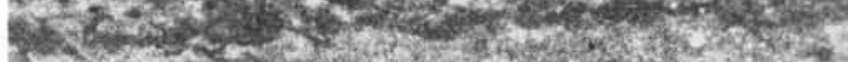

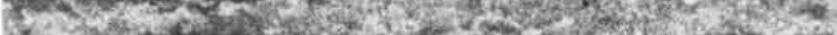
b.

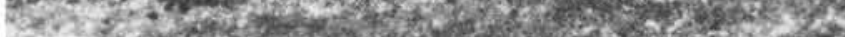

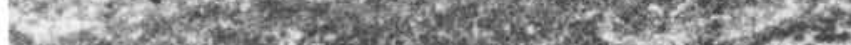

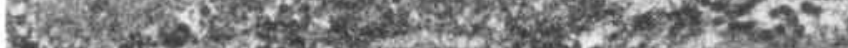
W.6. ins Fers

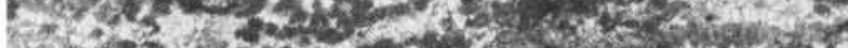

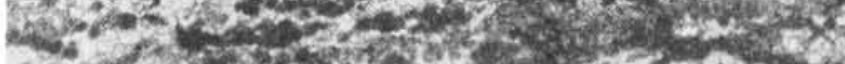

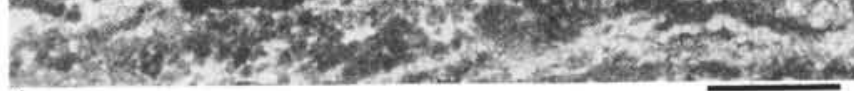

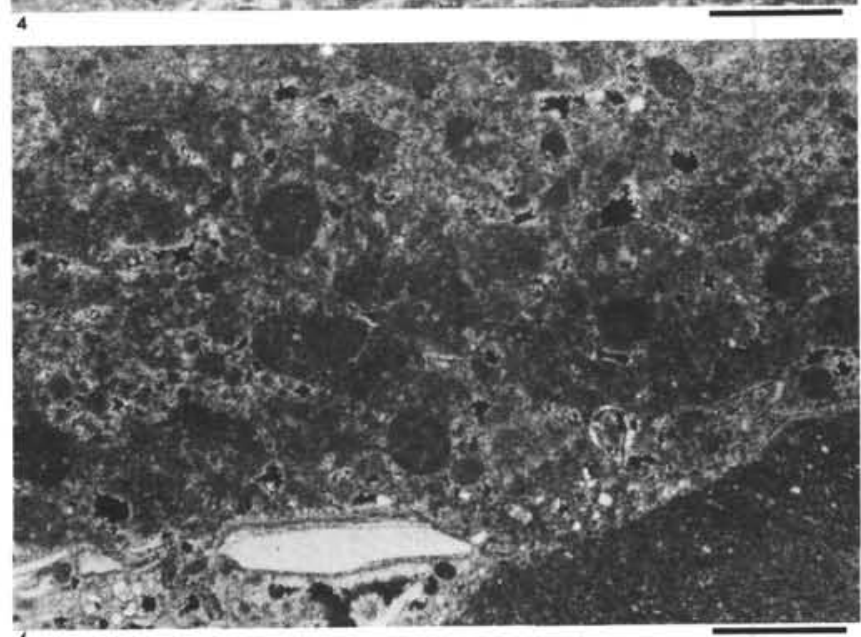

